\title{
FISCAL DATA REVISIONS IN EUROPE
}

by Francisco de Castro, Javier J. Pérez and Marta Rodríguez-Vives 


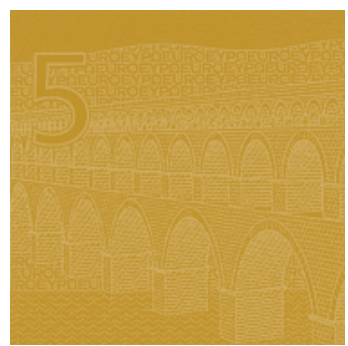

\title{
WORKING PAPER SERIES
}

NO I342 / MAY 20II

\section{FISCAL DATA REVISIONS IN EUROPE '}

\author{
by Francisco de Castro ${ }^{2}$, Javier J. Pérez ${ }^{2}$ \\ and Marta Rodríguez-Vives ${ }^{3}$
}
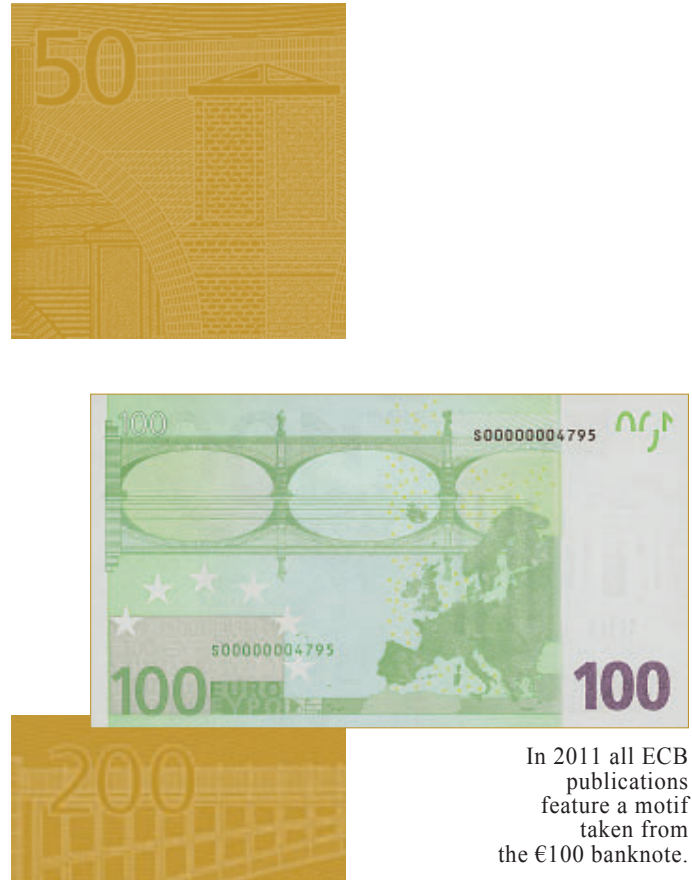

NOTE: This Working Paper should not be reported as representing the views of the European Central Bank (ECB).

The views expressed are those of the authors and do not necessarily reflect those of the $E C B$.

This paper can be downloaded without charge from http://www.ecb.europa.eu or from the Social Science Research Network electronic library at http://ssrn.com/abstract_id=1816325.

I The views expressed in this paper are the authors' and do not necessarily reflect those of the Banco de España, the European Central Bank or the Eurosystem. A previous version of this paper was circulated under the title: "Is fiscal data reportingin Europe reliable". We thank Werner Bier, David de Antonio, Gábor Kiss, Alfonso Novales, Gabriel Pérez-Quirós, Ad van Riet, Matteo Salto, Nikolai Stähler, Ernesto Villanueva and participants at the XIII Encuentro de Economía Aplicada (Seville, Spain, June 2010), the Banco de España seminar (Madrid, November 2010), and the ESCB-WGPF Fiscal Workshop 2010 (June) (Krakow, Poland) for their comments. We also thank Richard Morris and Michal Slavik for sharing their real-time databaseon real GDP growth rates. 2 Banco de España, Madrid, Spain; e-mails: fcastro@bde.es and javierperez@bde.es 3 European Central Bank, Kaiserstrasse 29, D-603II Frankfurt am Main, Germany; e-mail: marta.rodriguez@ecb.europa.eu 
(C) European Central Bank, 2011

\section{Address}

Kaiserstrasse 29

60311 Frankfurt am Main, Germany

Postal address

Postfach 160319

60066 Frankfurt am Main, Germany

Telephone

+496913440

Internet

http://www.ecb.europa.eu

Fax

+496913446000

All rights reserved.

Any reproduction, publication and reprint in the form of a different publication, whether printed or produced electronically, in whole or in part, is permitted only with the explicit written authorisation of the ECB or the authors.

Information on all of the papers published in the ECB Working Paper Series can be found on the ECB's website, http://www. ecb.europa.eu/pub/scientific/wps/date/ html/index.en.html

ISSN 1725-2806 (online) 


\section{CONTENTS}

Abstract

Non-technical summary

1 Introduction

2 The real-time dataset

2.1 Government deficit data source

2.2 Other variables

2.3 Some definitions

2.4 Unconditional properties of the sample

3 Rationality of revisions

3.1 News or noise?

3.2 More on the rationality of revisions: additional variables

3.3 Deepening the understanding of the results 22

4 Conclusions

References

Figures and tables

Appendix 


\begin{abstract}
Public deficit figures are subject to revisions, as most macroeconomic aggregates are. Nevertheless, in the case of Europe, the latter could be particularly worrisome given the role of fiscal data in the functioning of EU's multilateral surveillance rules. Adherence to such rules is judged upon initial releases of data, in the framework of the so-called Excessive Deficit Procedure (EDP) Notifications. In addition, the lack of reliability of fiscal data may hinder the credibility of fiscal consolidation plans. In this paper we document the empirical properties of revisions to annual government deficit figures in Europe by exploiting the information contained in a pool of real-time vintages of data pertaining to fifteen EU countries over the period 1995-2008. We build up such real-time dataset from official publications. Our main findings are as follows: (i) preliminary deficit data releases are biased and non-efficient predictors of subsequent releases, with later vintages of data tending to show larger deficits on average; (ii) such systematic bias in deficit revisions is a general feature of the sample, and cannot solely be attributed to the behaviour of a small number of countries, even though the Greek case is clearly an outlier; (iii) Methodological improvements and clarifications stemming from Eurostat's decisions that may lead to data revisions explain a significant share of the bias, providing some evidence of window dressing on the side of individual countries; (iv) expected real GDP growth, political cycles and the strength of fiscal rules also contribute to explain revision patterns; (v) nevertheless, if the systematic bias is excluded, revisions can be considered rational after two years.
\end{abstract}

JEL Classification: E01; E21; E24; E31; E5; H600.

Keywords: data revisions; real-time data; news and noise; fiscal statistics; rationality. 


\section{Non-technical summary}

The international press has been echoing, especially since October 2009, the strong and recurrent revisions to the Greek fiscal figures. Indeed, even though Greek data have been under scrutiny by the European Commission (Eurostat) at least since the early 2000s, renewed attention is being paid to this case. After almost two decades of Excessive Deficit Procedure (EDP) missions to Greece led by Eurostat, as late as November 2010 Eurostat still expressed reservations on the quality of the data reported by Greece's statistical institute (NSSG) for 2009, on issues such as social security funds' accounting, the classification of some public entities or the recording of off-market swaps.

Recently, some voices have been wondering whether revisions to Greek data revisions are representative of the Europe's fiscal reporting system or, conversely, they are just an isolated occurrence that can be explained by Greece's idiosyncratic factors. In this respect, the European Commission stated that "EU fiscal data were generally of high quality and Greece represented a one-off problem. However, it cautioned that it lacked audit powers and so relied heavily on the goodwill and integrity of member-states to supply accurate data” (FT, 12 January 2010). In the same fashion, the President of the ECB recently stated that "while the government finance statistics of the overwhelming majority of the Member States is reliable, this does not yet apply to all of them".

Beyond the Greek case, revisions of fiscal data have been reported as being sizeable in some European countries (Gordo and Nogueira Martins, 2007; Balassone et al., 2007). The reporting of fiscal data is at the heart of EU's multilateral surveillance rules, as adherence to such rules is judged upon initial data releases by EU Member States. Under the Stability and Growth Pact (SGP), any deviation of government deficits from the reference value of $-3 \%$ of GDP in the base year (not considered to be corrected over a given forecast horizon) leads to the adoption of corrective actions. In this case, the country concerned has to engage in a path of deficit reduction to be approved by the Council of Ministers of the European Union. Frequent and/or sizeable revisions of fiscal data may give rise to concerns about the reliability of the official EDP statistics used in the monitoring of the SGP.

Even though the production of fiscal data in Europe is the responsibility of independent national statistical institutes and is subject to scrutiny by the European Commission (Eurostat), from a political economy point of view some governments might have incentives to resort to creative accounting practices so that initially released figures could be distorted (see Kohen and Van de Noord 2005; Leal et al. 2008). Indeed, as regards concerns on fiscal statistics, some official communications point to "the need and means to upgrade the quality of budgetary statistics". In addition to the issue of statistical reliability, frequent past data revisions imply shifts in 
subsequent targeted/projected paths over the medium term given that government targets and projections are linked to base years when these targets/projections are produced. When sizeable fiscal data revisions become a stylised fact, the credibility of government targets is at stake. In the cases in which revisions do not present a clear recurrent pattern but are nonetheless frequent, the comparison of successive paths of government targets might be blurred, and may eventually undermine the soundness and consistency of fiscal policy choices over time.

Our findings suggest that the reporting system of fiscal data (i.e. general government deficit) in the EU can be improved. This general conclusion is substantiated by a number of facts, the main ones being the following.

First and foremost, most preliminary government deficit data releases are biased and nonefficient predictors of subsequent releases, with later vintages of data tending to show larger deficits than indicated by earlier data releases on average; nevertheless, if the systematic bias is excluded, revisions can be considered rational after two years. In addition, on average, small countries and/or countries not subject to EDP procedures along the analysed time period make a more rational use of the available information than large countries and/or countries subject to EDP procedures.

Second, such systematic bias in government balance revisions cannot solely be attributed to the behaviour of a small number of countries; it is rather a general feature of the sample, although the Greek case is clearly an outlier in the group of analyzed countries.

Third, the presence of stringent and binding fiscal rules contributes to enhancing the rationality of (earlier) fiscal data releases.

Fourth, Eurostat's decisions and methodological clarifications leading to forced data revisions explain a great deal of the bias towards larger deficits, providing some evidence that some individual countries might have distorted preliminary releases of data by using accounting rules in a partial way.

Finally, expected real GDP growth and political cycles also explain revision patterns, with estimated signs supporting the hypothesis that governments tended to conceal deficits in electoral and pre-electoral years, and when the economic situation was adverse. 


\section{Introduction}

The international press has been echoing, especially since October 2009, the strong and recurrent revisions to the Greek fiscal figures. Indeed, even though Greek fiscal figures have been under scrutiny by the European Commission (Eurostat) at least since the early 2000s, renewed attention is being paid to this case. After almost two decades of Excessive Deficit Procedure (EDP) missions to Greece led by Eurostat, ${ }^{1}$ as late as November 2010 Eurostat still expressed reservations on the quality of the data reported by Greece's statistical institute (NSSG) for 2009, on issues such as social security funds' accounting, the classification of some public entities or the recording of off-market swaps. Figure 1 illustrates the successive revisions to Greek fiscal deficit figures reported over the period 1999-2009.2

Recently, some voices have been asking whether revisions to Greek fiscal data are representative of Europe's fiscal reporting system or, conversely, they are just an isolated occurrence that can be explained by Greece's idiosyncratic factors. In this respect, the European Commission stated that "EU fiscal data were generally of high quality and Greece represented a one-off problem. However, it cautioned that it lacked audit powers and so relied heavily on the goodwill and integrity of member-states to supply accurate data" (FT, 12 January 2010). In the same fashion, the President of the ECB recently stated that "while the government finance statistics of the overwhelming majority of the Member States is reliable, this does not yet apply to all of them". ${ }^{3}$

Beyond the Greek case, revisions of fiscal data have been reported as being sizeable in some European countries (Gordo and Nogueira Martins, 2007; Balassone et al., 2007). This is exemplified in Figure 1 for the budget deficit data in the cases of Italy and Portugal in the early 2000s. Nonetheless, other countries such as Spain or Germany have revealed more stable revision patterns, as also illustrated in Figure 1.

The reporting of fiscal data is at the heart of EU's multilateral surveillance rules. Adherence to such rules is judged upon initial data releases by EU Member States, in the framework of

\footnotetext{
1 The first EDP mission to Greece took place in 1993.

${ }^{2}$ A comprehensive report on the reasons for the exceptional revisions to the Greek data since 2004 can be found at Eurostat webpage: http://epp.eurostat.ec.europa.eu.

3 Opening address by Jean-Claude Trichet, President of the ECB at the fifth ECB conference on statistics "Central bank statistics: what did the financial crisis change?", Frankfurt, 19 October 2010. The complete paragraph of the quote is: "First, the reliability of the general government statistics underlying the Excessive Deficit Procedure and the Stability and Growth Pact must be guaranteed when they come out. While the government finance statistics of the overwhelming majority of the Member States is reliable, this does not yet apply to all of them. Yet as we are in a highly integrated union, we need reliable statistics not just from the majority of Member States - we need it from each and everyone, no matter how large or how small the country is. We have seen that the potential for loss of credibility affects the entire union".
} 
the EDP Notifications ${ }^{4}$, one of the bases of Europe's Stability and Growth Pact (SGP). Under the SGP, any deviation of government deficits ${ }^{5}$ from the reference value of $-3 \%$ of GDP in the base year (not considered to be corrected over a given forecast horizon) leads to the adoption of corrective actions. In this case, the country concerned has to engage in a path of deficit reduction to be approved by the Council of Ministers of the European Union. Frequent and/or sizeable revisions of fiscal data may give rise to concerns about the reliability of the official EDP statistics used in the monitoring of the SGP. This is the case because revisions of fiscal data may imply that a country might appear ex-post as a no compliance case with the SGP, whereas at the time of the initial reporting this was not the case. This situation would have no consequences de facto as no EDP procedure is opened when the country breaches the $-3 \%$ of GDP deficit threshold in year $\mathrm{t}+2$ and beyond. As mandated in Article 6(1) of Regulation 479/2009, EU Member States shall inform Eurostat of "any major revision" of statistics to the already reported data. However, the legal act does not specify any thresholds.

Even though the production of fiscal data in Europe is the responsibility of independent national statistical institutes and is subject to scrutiny by the European Commission (Eurostat), from a political economy point of view some governments might have incentives to resort to creative accounting practices so that initially released figures are distorted (see Kohen and Van de Noord 2005; Leal et al. 2008). Indeed, as regards concerns on fiscal statistics, some official communications point to "the need and means to upgrade the quality of budgetary statistics". ${ }^{6}$ In addition to the issue of statistical reliability, frequent past data revisions imply shifts in subsequent targeted/projected paths over the medium term given that government targets and projections are linked to the base year in which these targets/projections are produced. When sizeable fiscal data revisions become a stylised fact, the credibility of government targets is at stake. In the cases in which revisions do not present a clear recurrent pattern but are nonetheless frequent, the comparison of successive paths of government targets might be blurred, and may eventually undermine the soundness and consistency of fiscal policy choices over time.

\footnotetext{
${ }^{4}$ Refer to Section 2.1 for an explanation on the EDP reporting.

5 The reference's economic sector is the general government sector (S.13) in national accounts, which is composed by central government, state government (if applicable), local government and social security sub-sectors. For simplification, in our paper we refer to "government" as equivalent to "general government sector".

6 See Council Regulation No 2103/2005 (OJ L337, 22.12.2005, p. 1) amending Council Regulation (EC) No $3605 / 93$ as regards the quality of statistical data in the context of the excessive deficit procedure. Furthermore, the amendment of the Council Regulation (EC) No 365/2009 to strengthen the auditing powers of Eurostat to improve the quality of the fiscal data used under the EDP process (including the reliability) was adopted on 26 July 2010 (Council Regulation (EU) No. 679/2010). On borderline statistical issues see, for example, the ad-hoc Eurostat's advice in the clarification of complex statistical issues or the monitoring of the correct application of Eurostat Decisions.
} 
Revisions in government deficit figures should, in principle, be explained by updates in the underlying statistical sources and/or by methodological improvements and changes in accounting standards (see McKenzie, 2006, and Bier et al., 2004). Due to the fact that national statistical authorities have up to four years to provide final data on government deficit (and debt) figures, there are inevitable margins of uncertainty in relation to first releases of figures. Even if these changes may lead to an improvement in the reliability of the fiscal data, they may also complicate the EDP process, if the values of the EDP government deficit (or surplus) for a given year systematically change whenever new data are notified. In addition, revisions to the government deficit and debt-to-GDP ratios could stem from revisions in nominal GDP (denominator effect).

The literature analysing revisions of fiscal data is relatively scarce. Exceptions are Balassone et al. (2006, 2007), that compare public deficits and changes in debt as alternative fiscal indicators in Europe; on the basis of their analyses and some case studies for the period 20002004, they argue that one of the shortcomings of the deficit indicator is the fact that it is subject to significant revisions. On different grounds, but also for EU countries, Bier et al. (2004), and Gordo and Nogueira Martins (2007) follow descriptive approaches to analyse the properties of the revisions in EDP deficit and debt figures, mainly by analysing the size of the revisions, the size of deficits or the volatility of the revisions.

In this paper, we extend the literature that analyses the properties of fiscal data revisions in Europe along the lines of the related literature on revisions of macroeconomic variables (Aruoba 2008; Clements and Galvao, 2010; Coenen et al., 2005; Croushore and Stark 2001; Garrat and Vahey 2006; Patterson and Heravi 2004; Swanson and van Dijk 2006; and the references quoted therein). In doing so, we aim at addressing the following issues for general government deficit statistics: are initial fiscal data releases unbiased estimates of the final values?; are revisions large compared to the initially reported values?; are initial releases rational forecasts of finally revised government deficits?; and, are revisions predictable using the information set at the time of the initial reporting? ${ }^{7}$

The standard analyses in the literature look at the $n$ vintages of a given (long) time series (typically US quarterly GDP or Industrial Production). On the contrary, we analyze the $n$ vintages of (short) government deficit time series for a cross-section of fifteen EU countries (data from 1995 to 2008). We use pool estimations to answer the above questions. This is the first paper to deal with the issues at hand using cross-section data. Furthermore, along the

\footnotetext{
7 The literature has analysed extensively the properties of revisions to fiscal projections. For a survey see Leal et al. (2008). A recent contribution is von Hagen (2011).Within this branch of the literature, Beetsma et al. (2011) analyse the underlying reasons behind deviations from budgetary plans specified in Stability and Convergence Programmes. They conclude that fiscal plans tend to be optimistic when compared with Autumn t-1 estimates of first-release outcomes for year $t$.
} 
lines of Swanson and van Dijk (2006), we examine the entire revision history of government deficits. This means that for each calendar date, we cover a complete historical record of the actual values available at different release dates. Hence, we can study the behaviour of the entire revision process of the variable of interest in detail, and analyse up to what point a preliminary release is a reliable estimate of the final data.

The rest of the paper is organised as follows. Section 2 describes the data used in the paper and provides some descriptive statistics. In Section 3, we tackle the issue of rationality of early releases and the relation between different vintages of data. Firstly, we test the news vs. noise hypotheses, carrying out the standard analysis but with pooled data; secondly, we incorporate additional explanatory variables, like real-time real GDP growth forecasts, the distance to the next general election, the European Commission's fiscal rule index and a set of dummy variables that measure Eurostat's methodological decisions on borderline and pending statistical issues. Finally, Section 4 provides the main conclusions of the study.

\section{The real-time dataset}

\subsection{Government deficit data source}

In the framework of the Excessive Deficit Procedure (EDP), Eurostat regularly publishes via official press releases government deficit actual data (statistics), compiled from data notified by EU Member States. Notifications have a biannual frequency. Council Regulation (EC) 3605/93 stated that Member States had to report biannually, in Spring and Autumn, ${ }^{8}$ actual government deficits figures ${ }^{9}$ to the European Commission (Eurostat). Actual data (statistics) published in year t have to cover year t-4 up to year t-1 figures (4 years).

We use these publicly available press releases by Eurostat as published from Spring 1999 (news release 20/99, published on 8 March 1999) to October 2009, to build up our database for fifteen EU countries, namely Belgium, Germany, Greece, Spain, France, Italy, Luxembourg, Netherlands, Ireland, Austria, Portugal, Finland, Denmark, Sweden and the United Kingdom, for the period 1995 to 2008. Along the reporting period covered by our sample two key institutional pieces were broadly stable: a homogeneous fiscal policy framework (SGP) and a homogeneous monetary policy framework (conducted by the European Central bank in the case of euro area countries).

\footnotetext{
8 Since the adoption of the Council Regulation (EC) 2103/2005 amending Council Regulation (EC) 3605/93, the reporting deadlines are before 1 April and 1 October of each year - instead of 1 March and 1 September, as initially mandated.

9 According to Article 2 (2) of the Council Regulation (EC) No 479/2009, "Actual government deficit and government debt level figures means estimated, provisional, half-finalised or final results for a past year".
} 
All in all, our sample covers 15 countries, 2 press releases per year reporting 4 years of statistics, and 14 years of data; given that different vintages of data contained a different amount of information, our sample contains 1320 data points, i.e. slightly less than $15 \mathrm{x} 2 \mathrm{x}$ 14 x 4 points. Our dataset contains eight vintages for years 1998 to 2005, six vintages for the years 1997 and 2006, four vintages for years 1996 and 2007, and two vintages for years 1995 and 2008.

In order to provide a broader perspective to EU fiscal data revisions, we also added as a memorandum item in some tables the US case for a sample period comparable with that used for European countries. US government deficit data are based on the National Income and Products Accounts (NIPA) methodology, which deviates to some extent from the SNA2008, and does refer to the federal government (i.e. central government). We use data for the period 1995-2009 that were released on a quarterly basis between March 2001 and September 2010 by the Federal Reserve (in the context of the Flow of Funds Accounts). Thus, we have 243 data points given that different vintages of data contained a different amount of information with a maximum of 19 revisions for each year containing the whole history of data releases for six years, i.e. 1996-2005. After 2 years, data are barely revised though. Nonetheless, in order to keep consistency with the European countries, only the releases corresponding to the first and the third quarters in each year have been used to gauge the relevant statistics.

\subsection{Other variables}

We have also compiled a number of other variables, which will be introduced in different parts of the analysis.

First, revisions to government deficit-to-GDP figures might be partly due to revisions in macroeconomic aggregates, given the role of nominal GDP as denominator of the ratio. We compiled revisions to GDP statistics from EDP notifications (press releases) as described above for government deficit figures.

Second, revisions in fiscal statistics can be due to imperfections in the data collection process and incomplete information at the time of initial reporting. For instance, data from local governments (and state governments when applicable) are typically available with a longer time lag.

Third, political economy considerations suggest that governments may have some incentives to conceal deficits if macroeconomic conditions are adverse. This is the case because unfavourable economic conditions, per se, worsen government deficits, in particular via the operation of automatic stabilizers. In such situation, a government might decide to influence the Statistical Institute, so that it reports a lower-than-observed deficit, postponing part of the 
increase in the deficit for subsequent revisions (most likely in good times). As a way of testing these hypotheses, we use a real-time dataset of real GDP growth (statistics and projections by the European Commission) for the 15 countries included in our study. In order for the exercise to mimic as much as possible the constraints and incentives faced by governments, this database resembles the structures of vintages of fiscal data revisions, and has been compiled directly from European Commission reports. ${ }^{10}$

Fourth, political budget cycles may influence the incentives of governments to report true fiscal figures, in particular because of the political costs derived from the initiation of an EDP procedure; in addition, a government may increase spending prior to an election and hide the emerging budget deficit, exploiting temporary information asymmetries. ${ }^{11} \mathrm{We}$ aim at capturing these effects by including country dummy variables that display a value of one in an election year and a zero otherwise. We took these data from Armingeon et al. (2008) for the period 1999-2005, and extended the variables by ourselves for 2006-2008. The variables used in the empirical analysis of Section 3 will be the standard ones in the literature: the election dummy as such, the election dummy lagged (pre-election year) and moved forward (postelection year), and a transformation of the original variable to measure proximity to elections, computed as a continuous variable as follows (see Franzese, 2000, 2002, Mink and de Haan, 2005). If the day when the election takes place lays in the current year $t$, the indicator, call it ELEC, at $\mathrm{t}$ takes the value: ELEC $=[(\mathrm{M}-1)+\mathrm{d} / \mathrm{D}] / 12$, where $\mathrm{M}$ is the month of the election, $d$ is the day of the election and $D$ is the number of days in that month. For the year prior to the election year the indicator takes the value: ELEC $=[12-(\mathrm{M}-1)-\mathrm{d} / \mathrm{D}] / 12$. For all other years the value of the indicator is zero.

Fifth, we took the fiscal rule index constructed by the European Commission in order to assess to what extent revision patterns are affected by the presence of different types of fiscal rules insofar as they may pose a permanent constraint on fiscal policy, expressed in terms of a summary indicator of fiscal outcomes, such as the government budget balance, debt, expenditure, or revenue developments. The role of fiscal rules in this framework is assessed because they aim at not only enhancing budgetary discipline, but also fostering policy coordination between different levels of government. Moreover, fiscal rules may further contribute to the reduction of uncertainty about future fiscal policy developments. However, fiscal rules can only yield these benefits if appropriate institutions for monitoring and enforcement mechanisms are in place, or if they are supported by strong political commitment.

\footnotetext{
10 We are greatly indebted to Richard Morris and Michal Slavik for sharing with us their real-time database on real GDP growth (data and EC projections).

11 On the role of electoral cycles on budgetary outcomes see, for example von Hagen (2010), Hallerberg et al. (2007) or Mink and de Haan (2005), and the references quoted therein.
} 
This index is based on all types of numerical fiscal rules (budget balance, debt, expenditure, and revenue rules) at all levels of government, in force in the period 1990-2008. The index of strength of fiscal rules uses information on (i) the statutory base of the rule; (ii) the body in charge of monitoring the respect of the rule; (iii) the body in charge of enforcement of the rule; and (iv) the enforcement mechanisms relating to the rule. It is constructed by summing up all fiscal rule strength indices in force in the respective Member State weighted by the coverage of general government finances of the respective rule (i.e. public expenditure of the government sub sector(s) concerned by the rule over total general government expenditure). If two rules apply to the same general government sub-sector, then the rule with the higher fiscal rule strength index score obtained weight one, while the other weaker rule was assigned weight 0.5 .

Finally, we compile dummy variables that encompass revisions to government deficit figures due to methodological improvements or clarifications, as mandated by Eurostat. GDP revisions and political cycles' influences reflect idiosyncratic country factors behind deficit revisions, while interventions by Eurostat should represent common improvements of the statistical system. In this respect, apart from general improvements in the European statistical system, the so-called Eurostat decisions reflect the need for detailed monitoring of practices by national statistical institutes that often tend to exploit to the limit the interpretation of existing legislation, typically aiming at concealing certain operations/issues that could increase government deficits. In this respect, a majority of Eurostat decisions lead to an increase in the deficit of the country concerned.

The compilation of these variables deserves some attention. Methodological improvements can be due to several reasons: (i) the implementation of Eurostat's decisions on complex statistical borderline issues ${ }^{12}$; (ii) Eurostat's advice clarifying the implementation of the national accounts framework or due changes in accounting methods (for instance, full accrual recording). The metadata information necessary to create the dummy variables has mainly been obtained from the annexes to EDP notifications as published in Eurostat's bi-annual press releases. ${ }^{13}$ It must be noted that there is a substantial increase of information published since the systematic publication on the specific reasons for major revisions (Annex 1 of the Eurostat's press releases), which started in Autumn 2005 EDP press release. In notifications prior to 2005, some metadata information has been identified under the sections "reservations and amendments", and so we had to exert some judgement.

12 See for a comprehensive list of the methodological decisions since 1997: http://epp.eurostat.ec.europa.eu/portal/page/portal/government_finance_statistics/methodology/decisions_for_GFS

13 In the case of Greek figures it was also necessary to resort to the report on Greek government deficit and debt statistics from the European Commission (Eurostat) (8 January 2010). 
Some remarkable examples of events included in the dummy variables (see Table A1 for all event) are worth mentioning: Greek data was revised to a large extent due to the recording of EU transfers (2001-2007), hospital expenditures and assumption of liabilities (2001-2004), military expenditure (2000-2003), or securitisation operations (1997-1998); Denmark and Sweden had observations (2003-2005) strongly impacted by the Eurostat's decision on the reclassification of funded pension schemes (2 March 2004); in the case of Belgium, Eurostat amended its deficit (and debt) notified in Spring 2007 for the years 2005 and 2006 in relation to the assumption by the government in 2005 of 7,400 million euro ( $2.5 \%$ GDP) of the debt of the SNCB (railway public company); for Spain, in Autumn 2007, the deficit for the period 2003-2006 was revised to be in line with Eurostat's advice on the reclassification of capital injection into ADIF (railway public company) as capital transfers; finally, the change from ESA79 to ESA95 affected all countries in the Spring 2000 EDP Notification, also for the back data from 1996 to $1998 .{ }^{14}$

\subsection{Some definitions}

The variable of reference we are interested in is the government deficit (-) / surplus (+) as a percent of GDP. Some remarks are worth mentioning in this respect. First, government deficit is defined as the balancing item net borrowing (net lending) (EDP B.9) of the general government sector. ${ }^{15}$ Second, GDP refers to annual nominal GDP as defined in National Accounts. Third, we are interested in revisions of the government deficit as a percent of GDP because the deficit-to-GDP ratio is indeed the policy variable of interest, and the basis over which policy decisions are taken.

The information in our dataset is organized according to the date in which the government deficit for a given year is published (a vintage). In this respect, the government deficit as a percent of GDP for year $t\left(d_{t}\right)$ published in a given date (vintage, $v$ ) will be denoted by $d_{t}^{v}$, for $v=1,2, \ldots, \mathrm{m}$.

Following the literature, a sequential revision is defined as

$r_{t}^{1}=d_{t}^{v+1}-d_{t}^{v}$

while the total or cumulative revision between the first and the $\mathrm{J}^{\text {th }}$ vintage is

$r_{t}^{J}=d_{t}{ }^{J}-d_{t}^{1}$

\footnotetext{
14 With the exception of Greece for the years 1996 to 1998. Greek back data figures based on ESA95 were published in Spring 2001.

15 As defined in the Protocol No. 12 on the excessive deficit procedure (EDP) annexed to the Treaty on the Functioning of the European Union and in Article 1(3) of Council Regulation (EC) No 479/2009.
} 
In particular, the total or cumulative revision between the first and the last vintage would be $r_{t}^{m}=d_{t}^{m}-d_{t}{ }^{1}$. Given the semi-annual nature of our data and the fact that a figure is considered to be final after four years, $m=8$ is the last vintage and consequently $r_{t}^{8}$ is the total or cumulative revision between the first and the final vintage.

\subsection{Unconditional properties of the sample}

Ideally, if well-behaved, revisions should: (i) have zero mean (each release should be an unbiased estimate of the final value); (ii) not be "large" in the sense of having a small variance compared to the variance of the final value; and (iii) the final revision should be unpredictable given the information set at the time of the initial announcement; if revisions were predictable, initial releases would not be optimal forecasts of the finally revised values.

Table 1 shows some descriptive statistics of cumulative revisions to deficit-to-GDP ratios (as defined in equation 2) for some selected vintages, for the pool of countries, as well as some country-specific information. It presents revisions after four years (final revisions within the 4-year reporting period), after three years, after one year, and within the first year of publication (Autumn EDP notification vs. Spring EDP notification). In each case we show the sample mean and the sample standard deviation. In addition, in the panel that displays total revisions $\left(\mathrm{r}_{\mathrm{t}}^{8}\right)$ we also show the "noise-to-signal ratio", defined as the standard deviation of revisions divided by the standard deviation of the initially reported value; this latter statistic gives an intuition about the size of final revisions relative to the size of the originally reported variables. Finally, for illustrative purposes, we also show some information for individual countries, even though it has to be taken with caution given the limited number of observations available.

Some features are worth highlighting from Table 1. First, for the pool of countries and years, cumulated revisions $\left(\mathrm{r}_{\mathrm{t}}^{8}\right)$ do present a significant negative bias, i.e. the final publication of the deficit of the government (after four years) tends to be, on average over countries and over years, higher than initially published. Within the first year $\left(r_{t}^{2}\right)$ the mean revision is not statistically different from zero, and also the revision after one year $\left(\mathrm{r}_{\mathrm{t}}^{3}\right)$, while after three years $\left(r_{t}^{6}\right)$ the significant negative bias is already noticeable. Moving across vintages, sequential revisions, on average over countries and years, turned out to go always in the direction of deepening the negative bias.

Second, there is heterogeneity across time in the sample. The negative bias shows up between 2000 and $2004\left(\right.$ for $\left.r_{t}^{8}\right)$, years that presented below-average GDP growth figures, especially in years 2001 to 2003. Interestingly, the first revisions available for $2008\left(r_{t}^{2}\right)$, also a "bad times" 
year, present a negative sign on average. 16 "Good times" years (1998-1999, 2005-2007) present either positive or non-significant total (or partial) revisions.

Third, there is cross-country heterogeneity in the sample. This is evident from the somewhat high standard deviations per year, so that hardly half of the computed sample means per year would be statistically different from zero. Nevertheless, the negative bias in total revisions $\left(r_{t}^{8}\right)$ seems to be a strong feature of our sample, as eleven out of fifteen countries show a negative mean of $r_{t}^{8}$.

Fourth, initially revised figures suffer little revision within the first year $\left(r_{t}^{2}\right)$, the most relevant from a policy point of view. This is observed for the pool, but also for individual countries. Indeed, revisions within the first year were on average very small for most countries, except for Greece ( -0.35 points of GDP), Portugal (-0.19 points of GDP), Luxembourg (+0.66 points of GDP) and, to a lesser extent, Belgium (-0.11 points of GDP). Only for Germany and Italy, i.e. some $30 \%$ of the sample, the sign of the first revision $\left(\mathrm{r}_{\mathrm{t}}^{2}\right)$ was a correct indicator of the sign of the total revision $\left(r_{t}^{8}\right)$.

Finally, the "noise-to-signal ratio" of $0.43 \%$ of GDP in final revisions $\left(\mathrm{r}_{\mathrm{t}}^{8}\right)$ for the pool of countries and years, given a sample mean of $-0.34 \%$ of GDP in absolute terms, indicates that final revisions are sizable compared to original values. There is substantial cross-country dispersion in this indicator, with Austria, Greece and Belgium in the upper extreme (with values of 1.45, 1.05 and 0.68, respectively), and Germany, the United Kingdom and Finland at the lower end of the distribution (with values of $0.07,0.08$ and 0.09 , respectively).

In Table 1 we also report some statistics for the US case for illustration purposes, as the number of available observations is limited (one per year, as explained in a previous subsection). As regards total revisions $\left(\mathrm{r}_{\mathrm{t}}^{8}\right)$, the mean over all years for the US is -0.14 (revision to more deficit), well below the mean deficit revision of -0.34 for the pool of European countries, but similar in size to countries like Germany or the United Kingdom. Nevertheless, most of the total revision was completed within the first year, a key difference with the average European country, and each one of them.

Table 2 shows some statistics of sequential revisions. These are revisions that occurred between two consecutive vintages, irrespective of the point in time in the overall revision process $\left(\mathrm{r}_{\mathrm{t}}{ }^{1}\right.$ as defined in equation 1). Sequential revisions were on average negative, though small, at half a tenth of a percentage point per vintage; indeed, eleven out of fifteen countries presented average negative sequential revisions, but only in five cases can the number be

16 "Bad time" periods led in many cases to the opening of several Excessive Deficit Procedures. Between 2001 and 2003 Portugal, France, and Germany were under EDP. In 2004 EDPs were opened for Greece and the Netherlands, while Italy and the United Kingdom were subject to an EDP in 2005 and 2006, respectively. 
considered as statistically different from zero, namely Austria, Greece, Italy, Portugal and Spain. In the latter three cases, the negative bias arises from a tendency to revise downwards whenever there was a revision (the three countries show a remarkable number of no-revisions, and a ratio of downwards-to-upwards revisions above 3). Greece shows a downward revision ratio totally out of line with the rest of countries, with a number close to $55 \%$; on the extreme, Luxembourg is the only case with a positive and significant average of sequential revisions, that at the same time shows one of the highest numbers of downward (negative) revisions (38\%). Even though sequential revisions do cumulate, on average, little by little to total revisions, there are some exceptional cases in which high revisions occurred from one vintage to the next (see "Minimum" and "Maximum" columns); these cases tend to be associated with Eurostat exceptional decisions, as discussed above.

Sequential revisions were not outstandingly frequent overall, with the notable exception of Greece, given the moderate standard deviations and the fact that in around $50 \%$ of the cases no revisions were observed (column "No revision ratio", pool of countries). Indeed, in seven countries, the percent of no-revisions was close to or above $60 \%$ (Finland, France, Germany, Italy, Netherlands, Portugal, and Spain), and thus the standard deviation of sequential revisions turned out to be low in those cases.

Table 2 also reports, as a memorandum item, statistics of sequential revisions for the US. The figures computed for the US are not too different from the average EU country: negative average sequential revision (though not different from zero in statistical terms), small standard deviation, and downward revisions outweighing upward ones. Two respects in which revisions differ are: (i) maximum and minimum revisions are substantially smaller; and (ii) the percent of no-revisions is in the upper range of EU countries. Point (i) might signal higher stability of the statistical reporting system itself, given that highest revisions (in absolute value) in the EU are due to Eurostat decisions clarifying borderline cases or introducing methodological improvements. Nonetheless, these discrepancies show up due to revisions mostly in small countries, while deeper inspection shows that these statistics in the US are broadly in line with those for the largest EU countries, especially Germany, France, Spain or the United Kingdom.

Revisions in government balances-to-GDP ratios can stem either from government balances, GDP figures or both, as shown in Table 3. Interestingly, despite revisions in GDP figures account for some share, revisions in deficit ratios are mainly due to genuine fiscal revisions. Table 3 shows that the contribution of revisions in nominal government balances is, on average, more than 10 times as large as the contribution of GDP revisions. In turn, the contribution of nominal GDP revisions to the overall revision in the deficit-to-GDP ratio was on average quite stable across vintages, moving from 0.00 in the first revision, to around 0.02 
in the $8^{\text {th }}$ revision on average after four years; this is in contrast with the tendency to higher deficit in subsequent revisions of this variable.

The descriptive analysis presented in tables 1, 2 and 3, can be summarized in the following stylized facts: (i) final, cumulated revisions do present a significant negative bias (higher deficit in the final vintage than initially published). This is a robust feature of the sample, even though there is cross-country heterogeneity; (ii) there is also heterogeneity across time, in such a way that government deficits initially reported for a "bad time year" (a year that displayed adverse or below-average economic circumstances) tend to be revised upwards (more deficits); (iii) revisions to deficit-to-GDP ratios are due to genuine fiscal revisions, i.e. mostly reflect revisions to nominal government deficit figures; (iv) even though sizeable sequential revisions do occur occasionally, they are on average small and negative, thereby contributing to the negative bias in total deficit revisions; (v) final revisions are sizable compared to initial releases; (vi) revisions to US fiscal data are commensurate to the average EU country, even though, in the latter case sequential revisions tend to be more volatile, in particular due to the existence of occasionally extreme values (Eurostat decisions); (vii) Greece is clearly an outlier in all considered respects. Therefore, the analysis so far leads us to conclude that the first two desired properties of revisions are not satisfied.

\section{Rationality of revisions}

The analysis in the previous Section hints that initial releases by national statistical authorities are not unbiased estimates of the final values, and that revisions are large compared to originally reported values. A significant mean revision would also imply some degree of predictability of the final value on the basis of previously reported data. In this Section we try to substantiate the previous preliminary conclusions based on descriptive statistics, by means of detailed econometric analysis. In particular, we aim at assessing to what extent initial releases are unbiased and rational forecasts of finally revised deficits. This analysis, given the structure of our dataset, will exploit and control for observed heterogeneity both across time and country dimensions.

\subsection{News or noise?}

Even though the presented descriptive statistics provide interesting information, they do not provide valid enough inference about how the information available is used, i.e. they do not provide a notion of the efficiency of the estimation process, in the sense of whether revisions between two consecutive vintages incorporate the relevant "news" embedded in the newly available information, or rather reflect "noise" in the production of the previous estimate. Research in the area of testing rationality of preliminary announcements is based mainly on 
the framework put forward by Mankiw and Shapiro (1986), linking the first and final releases of data. Their setup aims to determine whether $d_{t}{ }_{t}^{1}$ : (i) is a noisy estimate of the fully revised data $d_{t}^{m}$; (ii) is an efficient forecast of the fully revised data $d_{t}^{m}$; or (iii) neither of the two previous alternatives. In the first case, "noise", the initial preliminary announcement of the government deficit would be an observation of the final value of the government deficit, measured with error. This implies that the revision is uncorrelated with the final value but correlated with the data available when the announcement is made. Conversely, if the initial release is an efficient and rational forecast of the final estimate, "news", the revision should be correlated with the final value and uncorrelated with the first release data.

This setup can be used, in general, to link two consecutive vintages (Swanson and van Dijk, 2006). In the first case, "noise", the revision does not contain any new information. In the second case, "news", the change in the estimate of the variable of interest from one vintage to the next can be attributed to the incorporation of new information. The latter hypothesis is the most interesting from a theoretical point of view, given that the general goal of a sequence of revisions is to approach some "true" value of the variable of interest (benchmarking), following a learning path that incorporates new information at the time of each revision (Fixler, 2007). A standard way of testing for the "news" and "noise" hypotheses is as follows (Mankiw and Shapiro, 1986; Faust et al., 2005; Arouba, 2008). Let $r_{t}^{v+j, v}$ be the revision between vintage $v$ and $v+\mathrm{j}$, and consider the following regression framework

$r_{t}^{v+j, v}=\alpha_{1}+\beta_{1} d_{t}^{v}+\varepsilon_{t}^{v}$

$r_{t}^{v+j, v}=\alpha_{2}+\beta_{2} d_{t}^{v+j}+\varepsilon_{t}^{v+1}$

Testing for the "news" hypothesis amounts to not rejecting the null hypothesis $\mathrm{H}_{0}: \alpha_{1}=0$ and $\beta_{1}=0$, while at the same time rejecting $\mathrm{H}_{0}: \alpha_{2}=0$ and $\beta_{2}=0$. More intuitively, if $\alpha_{1}=0$ and $\beta_{1}=0$, revisions are not correlated with the estimate for vintage $v$; this does not imply automatically that they are correlated with the estimate for vintage $v+\mathrm{j}$, and so the second hypothesis has to be tested and rejected in order to confirm that indeed revisions, $r_{t}^{v+j, v}$, are correlated with the estimate corresponding to vintage $v+j, d_{t}^{v+j}$ (given that $\beta_{2} \neq 0$ ). In the same fashion, testing for the "noise" hypothesis amounts to not rejecting the null hypothesis $\mathrm{H}_{0}: \alpha_{2}=0$ and $\beta_{2}=0$, while at the same time rejecting $\mathrm{H}_{0}: \alpha_{1}=0$ and $\beta_{1}=0$. An important remark has to be made: both sets of hypotheses, $H_{0}: \alpha_{1}=0$ and $\beta_{1}=0$ and $H_{0}: \alpha_{2}=0$ and $\beta_{2}=0$, can be rejected or not rejected at the same time, thus leading to an inconclusive result. This result is particularly common in the literature when the mean revision is not equal to zero.

Table 4 shows the estimations corresponding to equations (3) and (4). All equations have been estimated by pooled generalized least squares, and include fixed effects when the 
relevant test indicates they are significant (redundant fixed effects test). ${ }^{17}$ The first column of Table 4 presents the revision between the initial releases of data $(v=1)$ and the final revisions (the $8^{\text {th }}$ publication); clearly, in this case, the hypotheses $\alpha_{1}=0$ and $\beta_{1}=0$ are rejected, not only because of the significant estimated country fixed effects, but also because $\beta_{1}$ turns out to be statistically different from zero and negative, and so the total revision is (negatively) correlated with the initially published figure. This result would give us some indication of "noise" in the revision process; nevertheless, the first column of the right panel of Table 4, that relates to the total revision, and uses as explanatory variable the final data releases (the $8^{\text {th }}$ publication), shows that the hypotheses $\alpha_{2}=0$ and $\beta_{2}=0$, are also rejected. Even accounting for the significance of the constant (fixed effects), the individual hypothesis $\beta_{2}=0$ is also rejected. Thus, both the "news" and the "noise" hypotheses are rejected in this case, signalling that the revision process is a mixture of "noise" and "news", and thus the statistical agencies only use partially the available information at each point of time.

In addition to the points made in the previous paragraph, the rest of the messages that can be extracted from the information included in Table 4 can be summarized as follows. Firstly, in general, the significantly estimated constants (general and country-specific) jointly with slope coefficients different from 1 suggest that there is some "unexploited" information in earlier vintages of data that could be used to forecast subsequent data releases; in this respect, the production process of fiscal data in our sample is not efficient. ${ }^{18}$ Secondly, Table 4 shows that as of vintage $v=4$, earlier vintages of data do not have forecasting power for final/total revisions (i.e. $\beta_{1}$ can be considered to be zero from a statistical point of view); leaving aside the constant/fixed-effects, this is an indication that indeed the revision process becomes more efficient from vintage 4 onwards. In fact, subtracting the significantly different from zero mean from the revisions and the vintages of data, the "news" hypothesis is not rejected for

\footnotetext{
17 As signalled by Vahid (1999) the classical homogeneity assumption in panel data analysis is that the slopes of the $\mathrm{N}$ cross sectional units are equal, after one allows for cross section specific or random fixed effects. This assumption is absolutely necessary and non-testable for the analysis of panel data with very small T. Even acknowledging the low power of equality-of-slopes tests across cross section units in our sample (as it is usually the case in most empirical analysis of this kind), we implemented pairwise tests that showed that the assumption is acceptable. Beyond statistical tests, the hypothesis seems reasonable on conceptual grounds. The selected sample period was on purpose starting in 1999, given that all considered countries have been subject since then to the same accounting rules, whose actual implementation is closely monitored by a common agency (Eurostat) that guarantees homogeneity and consistency of application of the rules. This should be true, on average, once controlling for country fixed effects.

18 Equations (3) and (4) have also been estimated for the US. Except for the first and second releases, both the news and noise hypotheses are accepted at conventional significant levels. However, due to the relatively low number of observations, estimates are highly imprecise and do not allow to draw credible conclusions.
} 
$v$ equal to 4 and 5. For $v$ equal to 6 and 7 the hypotheses $\beta_{1}=0$ and $\beta_{2}=0$ are not rejected, leaving the constant/fixed-effects as the only significant explanatory factors. ${ }^{19}$

\subsection{More on the rationality of revisions: additional variables}

Beyond the information contained in previous vintages and the presence of systematic biases, other explanatory factors may help understand the reasons behind government deficit revisions. We isolate two possible groups of additional determinants of revisions: the economic situation, as measured by real GDP growth forecasts, and the proximity of elections. If the cyclical situation is expected to be adverse, and/or if a general election is approaching, governments might have incentives to offer an overly optimistic view about the state of public finances, which would presumably lead to downward revisions in the future. Conversely, after being appointed in office, governments might be inclined to reassess previous budgetary situations, especially after changes in the sign of the government. In order to account for these factors we estimate an augmented version of equation (3), along the lines of the related literature (see for example Swanson and van Dijk, 2006, or Arouba, 2008),

$r_{t}^{8, v}=\alpha+\beta d_{t}^{v}+\gamma E_{H}\left[g_{H}^{v}\right]+\delta E_{H}\left[\operatorname{ELECTIONS}_{H}^{v}\right]+\varepsilon_{t}^{v}$

where $E_{H}\left[g_{H}^{v}\right]$ denotes expected output growth for the publication year of $d_{t}^{v}$, say $H$ (with $\mathrm{t}<\mathrm{H} \leq \mathrm{t}+4$ ), and $\mathrm{E}_{\mathrm{H}}\left[\right.$ ELECTIONS $_{\mathrm{H}}{ }^{\mathrm{v}}$ ] is a measure of the distance to elections also at the time of the publication of $d_{t}^{v}$, i.e. year $H$. The timing assumption is crucial. Indeed, we are interested in analyzing if the revision since $v$, that is $r_{t}^{8, v}$, could have been predicted at the time of the publication of the government deficit figure, $d_{t}^{v}$. In fact, at that very time is when the motivation to hide deficits for political or economic reasons should show up. Thus, our baseline hypothesis of political interferences in the data revision process would prescribe that, (i) $\gamma$ is positive, given that in bad times (negative growth) governments might have incentives to hide part of the deficit today, and accordingly revisions towards higher deficits could be expected, and (ii) $\delta$ is negative given that the proximity of an election would also lead a government to delay a revision towards higher deficit. ${ }^{20}$

\footnotetext{
${ }^{19}$ It is worth noting that the methodological change from ESA79 to ESA95 took place in spring 2000, leading to a revision of EDP figures for 1996, 1997 and 1998. Such change affected all countries simultaneously except Greece, whose deficit figures for 1997 and 1998 were revised one year after. Notwithstanding the fact that this is the only Eurostat-enforced decision affecting many countries simultaneously, this event might induce some crosssectional dependence. However, when we controlled for this factor with dummy variables for the relevant years point estimates in Table 4 barely changed and the conclusions drawn from it remained unaffected. This finding is consistent with Gordo and Nogueira Martins (2007), who provide descriptive evidence showing that the change to ESA95 was immaterial for the EDP reporting system.

20 These results are broadly consistent with those found in the literature for budgetary forecast errors and budgetary outcomes. See for example von Hagen (2010), Hallerberg et al. (2007) or Leal et al. (2008).
} 
Table 5 shows the results of the estimation of equation (5) for the complete history of revisions (from the first vintage on to the final one the $8^{\text {th }}$ vintage). Some points are worth highlighting. First, the evidence regarding the significance of the constant of the regression (or country fixed effects) still holds. Second, up to $v=3$ the preliminary data release is informative about future revisions but, as observed in the previous subsection, as of $v=4$ (i.e. after two years) it lacks forecasting power. Third, as regards elections, $\delta$ is negative and significant up to $v=3$ thus indicating that the proximity of an election can help forecasting an upcoming revision towards more deficit provided that the date the deficit to be revised refers to is relatively close; as of to $v=4$ though this variable looses significance. Finally, expected real GDP growth also shows up as significant in the year of the initial release and the next one, with $\gamma$ displaying the expected positive sign.

Summing up, two broad conclusions emerge. On the one hand, all the explanatory variables do have forecasting power on future revisions, making obvious the lack of rationality of initial releases of data as forecasts of finally revised data. On the other hand, once accounting for the constant/bias, as of release $v=4$ (i.e. after two years) revisions could be considered rational in the sense that none of the explanatory variables are significant (current release of data, expected real GDP growth, elections).

\subsection{Deepening the understanding of the results}

In this subsection we perform a number of exercises aimed, first, at deepening the understanding of the results and, second, at assessing their robustness.

In a first exercise we assess the robustness of the selected proxy for political cycles. We do so by including in our analysis a number of additional variables employed in the literature that studies political cycles (see von Hagen, 2010; Hallerberg et al., 2007; Mink and de Haan, 2005). Specifically, we include: (i) a pre-electoral year dummy, which takes a value of 1 for years preceding an election year, and zero otherwise; (ii) an electoral year dummy, which takes a value of 1 in years in which an election takes place and zero otherwise; (iii) a postelectoral year dummy that displays a value of 1 for a year after an electoral year and zero otherwise. Therefore, the indicator measuring proximity of elections is a combination of (i) and (ii), with weights given by the formulas described in Section 2.2.

The results are shown in Table 6 (only for $v=1$ for the sake of brevity). The pre-electoral dummy (column 4) is significant and negative, indicating that, on average, deficits corresponding to pre-electoral years tend to be revised upwards (towards more deficit) in subsequent data releases. This result is similar to the one using the proximity-of-elections variable (column 1). The coefficient of the electoral year dummy variable (column 3) presents 
the expected negative sign, but it is not significantly different from zero. A possible explanation can be derived from a class of models analyzing political cycles. As signalled by Mink and de Haan (2005), in this set of models it is assumed that the government uses shortterm excess borrowing as a hidden effort - that is, as a policy instrument unobservable to the electorate - in order to increase its probability of re-election. But borrowing extra money during a pre-election year is more difficult to hide compared to borrowing during an election year since information on the pre-election year's government deficit is likely to be published prior to the election date, so that the policy instrument would no longer be unobservable by the electorate, and thus may harm government's target of re-election. Consequently, the government has incentives to hide part of the actual deficit in a pre-election year and to revise it afterwards, once the election has taken place. Finally, the post-election year dummy (column 2) displays a weakly significant positive value, which can be interpreted as an indication that newly appointed governments tend to publish deficit figures for the previous year as they actually were or even worse (more deficit), because they can blame the previous administration.

In a second exercise, we run the same equations as in Table 6 but including the European Commission's fiscal rules index (FRI). Its inclusion did not alter the results, and the fiscal rules index turned out to be non-significant. This is explained because the FRI does not vary much over time except for significant changes in the country's budgetary framework of legislative nature. Therefore, the effect of the FRI is concealed by the country fixed effects needed in the estimation. Thus, in order to assess the specific role of the FRI aside from other country-specific factors, we estimated the same equations as in Table 6 without fixed effects and including the FRI. Table 7 shows that in this case, as expected, the coefficient of the FRI is positive and significant in all cases; in other words, the more stringent the fiscal rule, the more important its contribution to reducing the overall bias towards negative revisions. Accordingly, our results support the view that stronger and more binding fiscal rules also contribute to enhancing the credibility of (earlier) fiscal data releases. ${ }^{21}$

A third exercise aims at deepening the understanding of the reasons behind the negative bias in deficit revisions. Specifically, we ask ourselves the following question: is there some piece of the European statistical framework that might be conductive to this negative bias? In order to test this idea, we compiled all the revisions stemming from the implementation of Eurostat's decisions on preliminary country data and on Eurostat's clarifications of the ESA95 rules aiming at upgrading the quality of the whole reporting framework. All the events

21 The fact that national budgetary institutions are key determinants of fiscal forecast errors is now a solid stylized fact of the extant literature. Along these lines, Beetsma et al. (2011) find that medium term budgeting and stringent fiscal rules reduce the optimistic bias embedded in preliminary government forecast for the current year. 
considered are described in Table A1 of the Appendix. On the basis of the information in Table A1, we built up a dummy for each vintage of revisions. For example, the variable "Eurostat decisions at $v=2$ " includes all Eurostat-led revisions affecting second notifications; the same reasoning follows for subsequent vintages of data.

Table 8 shows the results for equation (5), but in this case adding each time the corresponding "Eurostat dummies". Some results are interesting. First, 27 out of the 28 coefficients shown display a negative sign: all Eurostat-induced revisions led to higher deficits on average in our sample. Second, the dummies help rationalize the heterogeneity previously captured by country fixed-effects as, after controlling for Eurostat's dummies, only four countries did present significant fixed effects, while the average in prior estimations was at or above ten; in addition, as of $v=3$ the redundant fixed effects test signals that there is no need to allow for cross-country heterogeneity by means of fixed effects. Finally, the overall bias gets reduced in absolute value and looses significance when compared to estimations conducted without Eurostat's dummies.

This evidence is consistent with two opposite points of view. On the one hand, one may claim that a big deal of the revisions were due to the still evolving nature of the European statistical system, with rules on borderline issues still to be fully settled. On the other hand, an alternative argument would be that individual countries tried to manipulate information in preliminary publications of data, given that ex-post revisions led to higher deficits, and this tendency could have been predicted in real-time; in addition to the information contained in earlier releases of data, electoral variables and the state of the economic cycle, some countries would have tried to stretch to the limit the common accounting rules, a fact that led Eurostat to closely monitor and unveil "window dressing" practices by individual countries.

Finally, tables 9 and 10 present results for two clusters of countries with economic meaning. First, we group countries according to their size in big and small countries. Second, we compare countries that were subject to at least one EDP procedure during the period covered by our sample with countries that never were under EDP in that period, i.e. that were considered to meet SGP provisions in all the years considered. Some results are interesting.

Table 9 presents the results for the two country size groups. The left panel of the Table shows that in both cases total/final revisions are predictable on the basis of the initial release of data and the bias (fixed-effects); moreover, in none of the cases has the $v=4$ data release explanatory power on subsequent revisions, even though the presence of a bias does lead to the rejection of the joint hypothesis of $\alpha_{1}=0$ and $\beta_{2}=0$. Leaving the existence of the bias aside, the "news" hypothesis is accepted for the case of the group of small countries, while in the case of large countries the "noise" hypothesis is accepted in the case $v=1$. Thus, small 
countries as a group seem to have behaved better with regard to using the information in preliminary data releases than large countries.

Table 10 illustrates he results for the grouping "EDP" vs. "non-EDP countries"). The same picture as before applies as regards the presence of a bias: this cannot be rejected in any grouping. Nevertheless, for EDP countries the noise hypothesis cannot be rejected, while for the group of non-EDP countries, for total revisions (case $v=1$ ), the news hypothesis cannot be rejected. Again, this means that countries that were not subject to an EDP procedure, as a group, followed a revision pattern more efficient than that followed by countries subject to an EDP procedure, a finding in line with a reasonable political economy prior.

\section{Conclusions}

Our findings suggest that the reporting system of fiscal data (i.e. general government deficit) in the EU can be improved. This general conclusion is substantiated by a number of facts, the main ones being the following.

First and foremost, most preliminary government deficit data releases are biased and nonefficient predictors of subsequent releases, with later vintages of data tending to show larger deficits than indicated by earlier data releases on average; nevertheless, if the systematic bias is excluded, revisions can be considered rational after two years. In addition, on average, small countries and/or countries not subject to EDP procedures along the analysed time period make a more rational use of the available information than large countries and/or countries subject to EDP procedures.

Second, such systematic bias in government balance revisions cannot solely be attributed to the behaviour of a small number of countries; it is rather a general feature of the sample, although the Greek case is clearly an outlier in the group of analyzed countries.

Third, the presence of stringent and binding fiscal rules contributes to enhancing the rationality of (earlier) fiscal data releases.

Fourth, Eurostat's decisions and methodological clarifications leading to forced data revisions explain a great deal of the bias towards larger deficits, providing some evidence that some individual countries might have distorted preliminary releases of data by using accounting rules in a partial way.

Finally, expected real GDP growth and political cycles also explain revision patterns, with estimated signs supporting the hypothesis that governments tended to conceal deficits in electoral and pre-electoral years, and when the economic situation was adverse. 


\section{References}

Armingeon, K., Gerber, M., Leimgruber, P., Beyeler, M. and Menegale, S. (2008), "Codebook: Comparative political data set I, 1960-2005". Institute of Political Science, University of Berne.

Aruoba, B. (2008), Data revisions are not well-behaved. Journal of Money Credit and Banking 40, pp. 319-340.

Balassone, F., D. Franco and S. Zotteri (2006), EMU fiscal indicators: a misleading compass? Empirica 33, pp. 63-87.

Balassone, F., D. Franco and S. Zotteri (2007), The reliability of EMU fiscal indicators: risks and safeguards. Temi di Discussione 633, Banca d'Italia, Rome.

Beetsma, R., B. Bluhm, M. Giuliodori, and P. Wierts (2011), From first-release to ex-post fiscal data: exploring the sources of revision errors in the EU. Mimeo.

Bier, W., R. Mink and M. Rodríguez-Vives (2004), Extended statistics for the support of the stability and growth pact. Hacienda Pública Española, Monografía 2004, pp. 35-63.

Clements, M. P. and A. B. Galvao (2010), First announcements and real economic activity, European Economic Review 54, pp. 803-817.

Coenen, G., A. Levin and V. Wieland (2005), Data uncertainty and the role of money as an information variable for monetary policy, European Economic Review 49, pp. 975-1006.

Croushore, D., and T. Stark (2001), A real-time data set for macroeconomists. Journal of Econometrics 105, pp. 111-130.

Faust, J., J. H. Rogers and J. H. Wright (2005), News and Noise in G7 GDP announcements. Journal of Money Credit and Banking 37, pp. 403-417.

Fixler, D. (2007), How to interpret whether revisions to Economic variables reflect News or Noise. OECD/Eurostat Task Force "Performing Revisions Analysis for Sub-National Ec. Statistics".

Franzese, R. J. (2000), "Electoral and Partisan Manipulation of Public Debt in Developed Democracies, 1956-1990", in R. Strauch, J. von Hagen (Eds), Institutions, Politics and Fiscal Policy, pp. 61-83. Dordrecht: Kluwer Academic Press.

Franzese, R. J. (2002), 'Electoral and Partisan Cycles in Economic Policies and Outcomes', Annual Review of Political Science 5, pp. 369-421.

Garrat, A. and S. P. Vahey (2006), UK real-time macro data characteristics. The Economic Journal 116, pp. 119-135.

Gordo, L. and J. Nogueira Martins (2007), How Reliable are the Statistics for the Stability and Growth Pact?. European Economy - Economic Papers, 273. 
Hallerberg, M., R. Strauch and J. von Hagen (2007), "The design of fiscal rules and forms of governance in European Union countries", European Journal of Political Economy 23, pp. $338-359$.

Kohen, V. and P. van de Noord (2005), Fiscal Gimmickry in Europe: One-Off Measures and Creative Accounting". OECD Economics Department Working Papers, No. 417.

Leal, T., J. J. Pérez, M. Tujula and J. P. Vidal (2008), Fiscal forecasting: lessons from the literature and challenges. Fiscal Studies 29, pp. 347-386.

McKenzie, R. (2006), Undertaking revisions and real-time data analysis using the OECD main economic indicators original release data and revisions database, OECD Statistics WP 2006/2.

Mink, M. and J. de Haan (2005), "Has the Stability and Growth Pact Impeded Political Budget Cycles in the European Union?," CESifo Working Paper Series 1532, CESifo Group Munich.

Patterson, K. D. and S. M. Heravi (2004), Revisions to Official Data on U.S. GNP: A Multivariate Assessment of Different Vintages. Journal of Official Statistics 20, pp. 573602.

Swanson, N. R. and D. van Dijk (2006), Are statistical reporting agencies getting it right? Data rationality and business cycle asymmetry. Journal of Business and Economic Statistics 24, pp. 24-42.

Vahid, F. (1999), "Partial pooling: a possible answer to 'To pool or not to pool' ", Chapter 17 in Cointegration, causality and forecasting, R. F. Engel and H. White (Eds.), Oxford University Press, New York.

von Hagen, J. (2010), "Sticking to fiscal plans: the role of institutions", Public Choice 144, pp. 487-503. 
Figure 1: Revisions to government deficit-to-GDP ratios in selected EU countries.
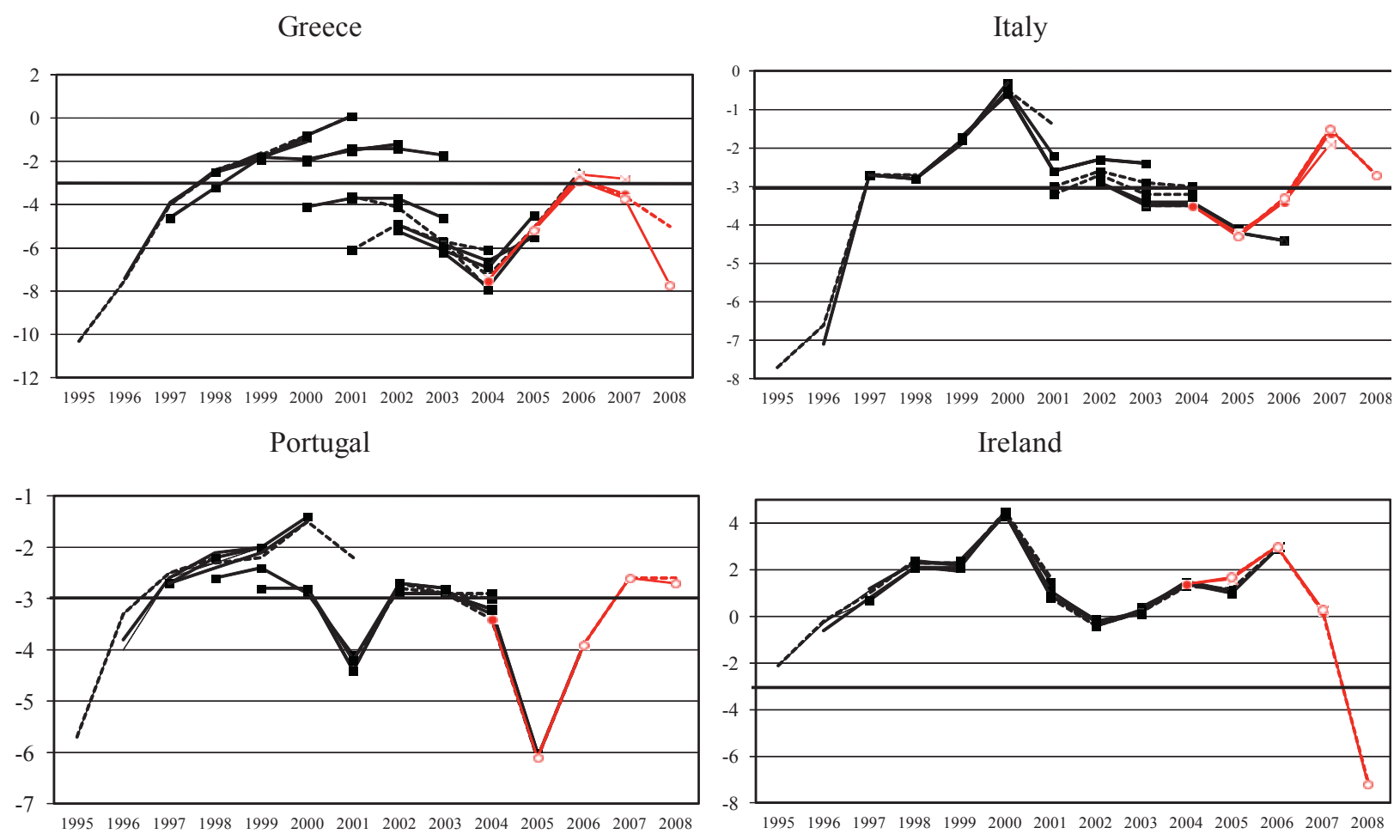

Spain

Germany
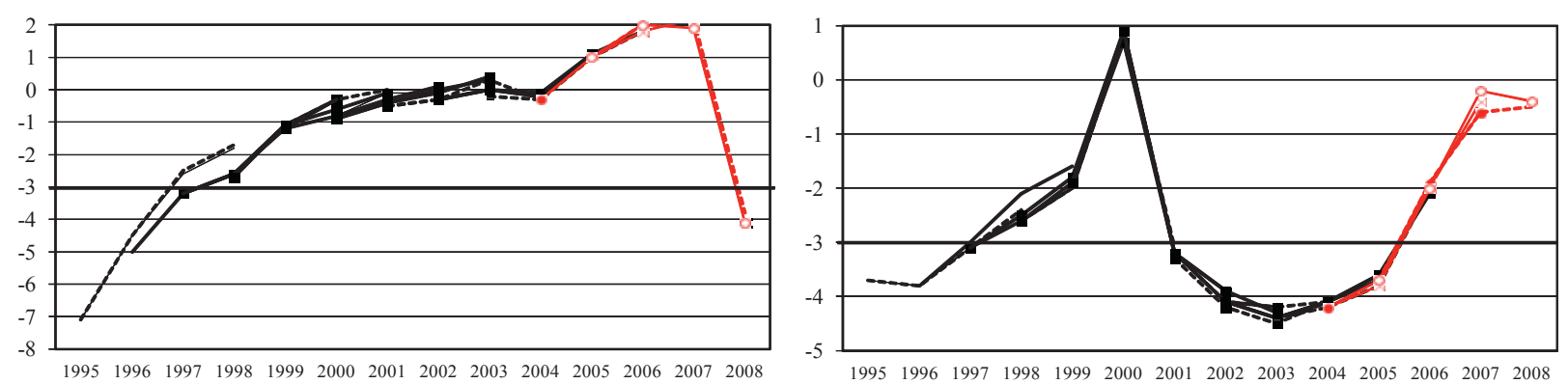

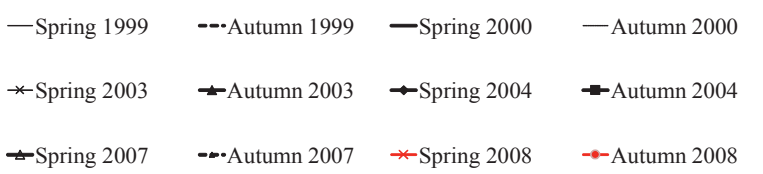

\begin{tabular}{|c|c|c|c|}
\hline *-Spring 2001 & -Autumn 2001 & ---Spring 2002 & —Autumn 2002 \\
\hline -•-Spring 2005 & -+•Autumn 2005 & ๑-Spring 2006 & -Autumn 2006 \\
\hline --.Spring 2009 & -Autumn 2009 & & \\
\hline
\end{tabular}


Table 1: Descriptive statistics of revisions to government deficit-to-GDP ratios, by year, for the pool of countries. Selected vintages.

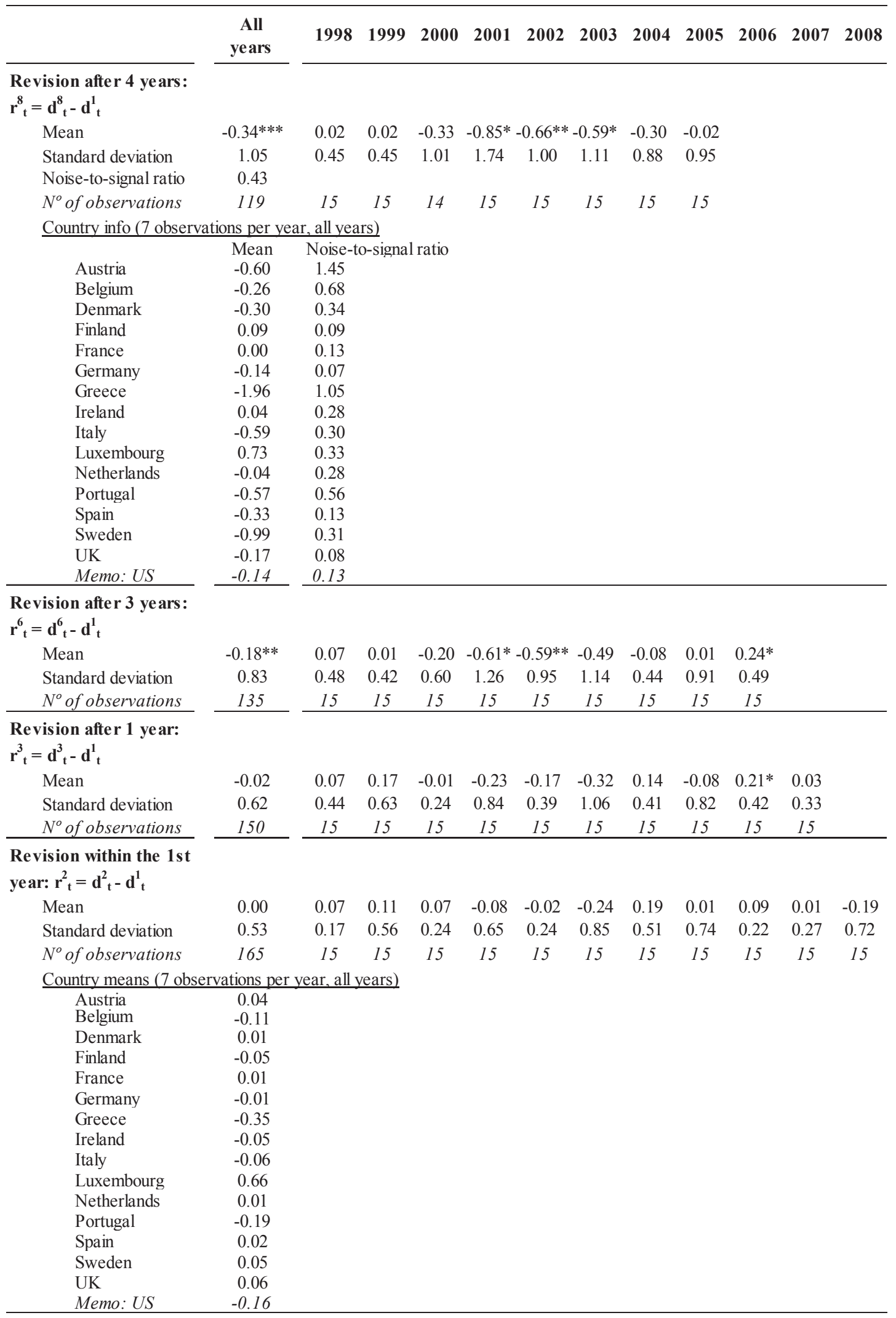

Note: The symbols *, $* *$ and $* * *$ denote significance at the $10 \%, 5 \%$ and $1 \%$ significance levels, respectively. 
Table 2: Sequential revisions to government deficit-to-GDP ratios.

\begin{tabular}{|c|c|c|c|c|c|c|c|c|}
\hline & Mean & $\begin{array}{r}\text { Standard } \\
\text { deviation }\end{array}$ & $\begin{array}{c}\text { Downward } \\
\text { revision } \\
\text { ratio } \\
\end{array}$ & $\begin{array}{c}\text { Upward } \\
\text { revision } \\
\text { ratio } \\
\end{array}$ & \begin{tabular}{|c|} 
No \\
revision \\
ratio \\
\end{tabular} & $\begin{array}{c}\text { Minimum } \\
\text { sequential } \\
\text { revision }\end{array}$ & $\begin{array}{c}\text { Maximum } \\
\text { sequential } \\
\text { revision } \\
\end{array}$ & $\begin{array}{c}\text { Number of } \\
\text { observations }\end{array}$ \\
\hline Pool EU countries & $-0.04 * * *$ & 0.34 & $30 \%$ & $21 \%$ & $49 \%$ & -2.90 & 2.00 & 1109 \\
\hline Austria & $-0.07 *$ & 0.32 & $38 \%$ & $14 \%$ & $49 \%$ & -2.50 & 0.40 & 74 \\
\hline Belgium & -0.03 & 0.31 & $23 \%$ & $28 \%$ & $49 \%$ & -2.40 & 0.40 & 74 \\
\hline Denmark & -0.03 & 0.42 & $32 \%$ & $30 \%$ & $38 \%$ & -1.20 & 1.20 & 74 \\
\hline Finland & 0.01 & 0.15 & $18 \%$ & $24 \%$ & $58 \%$ & -0.50 & 0.40 & 74 \\
\hline France & 0.00 & 0.06 & $12 \%$ & $12 \%$ & $75 \%$ & -0.20 & 0.20 & 73 \\
\hline Germany & -0.01 & 0.11 & $22 \%$ & $19 \%$ & $59 \%$ & -0.40 & 0.40 & 74 \\
\hline Greece & $-0.28 * * *$ & 0.79 & $54 \%$ & $20 \%$ & $26 \%$ & -2.90 & 1.80 & 74 \\
\hline Ireland & 0.01 & 0.15 & $31 \%$ & $34 \%$ & $35 \%$ & -0.40 & 0.50 & 74 \\
\hline Italy & $-0.05^{*}$ & 0.20 & $27 \%$ & $8 \%$ & $65 \%$ & -0.80 & 1.00 & 74 \\
\hline Luxembourg & $0.11 * *$ & 0.43 & $38 \%$ & $47 \%$ & $15 \%$ & -1.00 & 2.00 & 74 \\
\hline Netherlands & -0.01 & 0.15 & $26 \%$ & $18 \%$ & $57 \%$ & -0.60 & 0.50 & 74 \\
\hline Portugal & $-0.09 * *$ & 0.29 & $34 \%$ & $8 \%$ & $58 \%$ & -1.90 & 0.20 & 74 \\
\hline Spain & $-0.06^{* * *}$ & 0.17 & $32 \%$ & $9 \%$ & $58 \%$ & -0.90 & 0.20 & 74 \\
\hline Sweden & -0.08 & 0.42 & $27 \%$ & $22 \%$ & $51 \%$ & -1.70 & 1.70 & 74 \\
\hline UK & -0.01 & 0.12 & $32 \%$ & $20 \%$ & $47 \%$ & -0.30 & 0.50 & 74 \\
\hline \multicolumn{9}{|l|}{ Memorandum item: } \\
\hline USA & -0.01 & 0.28 & $21 \%$ & $11 \%$ & $68 \%$ & -0.80 & 0.30 & 85 \\
\hline
\end{tabular}

Note: The symbols *, ** and $* * *$ denote significance at the $10 \%, 5 \%$ and $1 \%$ significance levels, respectively. 
Table 3: Decomposition of revisions to government deficit-to-GDP ratios: deficit level, nominal GDP and other (residual) factors. Pool of years.

\begin{tabular}{|c|c|c|c|c|}
\hline & \multirow{2}{*}{$\begin{array}{c}\text { Mean of } \\
\text { revisions in } \\
\text { the deficit-to- } \\
\text { GDP ratio } \\
\end{array}$} & \multicolumn{3}{|c|}{ due to revisions in } \\
\hline & & $\begin{array}{l}\text { Nominal } \\
\text { deficit }\end{array}$ & $\begin{array}{l}\text { Nominal } \\
\text { GDP }\end{array}$ & Rest \\
\hline \multicolumn{5}{|l|}{$\begin{array}{l}\text { Revision after } 4 \text { years: } \\
r_{t}^{8}=d^{8}{ }_{t}-d^{1}{ }_{t}\end{array}$} \\
\hline Pool of countries & -0.34 & -0.39 & 0.02 & 0.03 \\
\hline Austria & -0.60 & -0.55 & 0.00 & -0.05 \\
\hline Belgium & -0.26 & -0.20 & 0.00 & -0.06 \\
\hline Denmark & -0.30 & -0.28 & 0.00 & -0.03 \\
\hline Finland & 0.09 & 0.14 & -0.02 & -0.04 \\
\hline France & 0.00 & -0.03 & 0.05 & -0.02 \\
\hline Germany & -0.14 & -0.12 & 0.03 & -0.04 \\
\hline Greece & -1.96 & -2.74 & 0.18 & 0.60 \\
\hline Ireland & 0.04 & 0.01 & -0.03 & 0.06 \\
\hline Italy & -0.59 & -0.58 & 0.04 & -0.05 \\
\hline Luxembourg & 0.73 & 0.70 & -0.09 & 0.12 \\
\hline Netherlands & -0.04 & -0.02 & 0.05 & -0.07 \\
\hline Portugal & -0.57 & -0.79 & 0.11 & 0.11 \\
\hline Spain & -0.33 & -0.39 & 0.01 & 0.05 \\
\hline Sweden & -0.99 & -0.66 & -0.10 & -0.22 \\
\hline UK & -0.17 & -0.26 & 0.03 & 0.06 \\
\hline \multicolumn{5}{|l|}{$\begin{array}{l}\text { Revision after } 3 \text { years: } \\
r_{t}^{6}=d^{6}{ }_{t}-d^{1}{ }_{t}\end{array}$} \\
\hline Pool of countries & -0.18 & -0.21 & 0.02 & 0.01 \\
\hline \multicolumn{5}{|l|}{$\begin{array}{l}\text { Revision after } 1 \text { year: } \\
r_{t}^{3}=d_{t}^{3}-d_{t}^{1}\end{array}$} \\
\hline Pool of countries & -0.02 & -0.01 & 0.01 & -0.01 \\
\hline \multicolumn{5}{|l|}{$\begin{array}{l}\text { Revision within the } 1^{\text {st }} \\
\text { year: } r_{t}^{2}=d^{2}{ }_{t}-d^{1}{ }_{t}\end{array}$} \\
\hline Pool of countries & 0.00 & 0.02 & 0.00 & -0.01 \\
\hline Austria & 0.04 & 0.04 & 0.00 & -0.01 \\
\hline Belgium & -0.11 & -0.11 & 0.00 & 0.00 \\
\hline Denmark & 0.01 & 0.08 & 0.00 & -0.07 \\
\hline Finland & -0.05 & -0.04 & 0.00 & 0.00 \\
\hline France & 0.01 & -0.01 & 0.01 & 0.01 \\
\hline Germany & -0.01 & 0.02 & 0.00 & -0.03 \\
\hline Greece & -0.35 & -0.31 & 0.00 & -0.05 \\
\hline Ireland & -0.05 & 0.00 & -0.03 & -0.01 \\
\hline Italy & -0.06 & -0.06 & -0.03 & 0.02 \\
\hline Luxembourg & 0.66 & 0.69 & -0.02 & -0.01 \\
\hline Netherlands & 0.01 & 0.01 & 0.01 & -0.01 \\
\hline Portugal & -0.19 & -0.18 & 0.01 & -0.02 \\
\hline Spain & 0.02 & 0.02 & 0.00 & 0.00 \\
\hline Sweden & 0.05 & 0.03 & 0.00 & 0.01 \\
\hline UK & 0.06 & 0.05 & 0.01 & 0.01 \\
\hline
\end{tabular}


Table 4: News-noise and unbiasedness tests.

\begin{tabular}{|c|c|c|c|c|c|c|c|c|c|c|c|c|c|c|}
\hline & \multicolumn{7}{|c|}{ Equation (3): $r_{t}^{8, v}=\alpha_{1}+\beta_{1} d_{t}^{v}+\varepsilon_{t}^{v}$} & \multicolumn{7}{|c|}{ Equation (4): $r_{t}^{8, v}=\alpha_{2}+\beta_{2} d_{t}^{8}+\varepsilon_{t}^{8}$} \\
\hline & $v=1$ & $v=2$ & $v=3$ & $v=4$ & $v=5$ & $v=6$ & $v=7$ & $v=1$ & $v=2$ & $v=3$ & $v=4$ & $v=5$ & $v=6$ & $v=7$ \\
\hline$d_{t}^{v}$ & $\begin{array}{c}-0.05^{* *} \\
(0.02)\end{array}$ & $\begin{array}{c}-0.03^{* * * *} \\
(0.01)\end{array}$ & $\begin{array}{c}-0.05^{* *} \\
(0.02)\end{array}$ & $\begin{array}{l}-0.02 \\
(0.02)\end{array}$ & $\begin{array}{l}-0.01 \\
(0.01)\end{array}$ & $\begin{array}{l}-0.01 \\
(0.01)\end{array}$ & $\begin{array}{l}-0.001 \\
(0.001)\end{array}$ & & & & & & & \\
\hline$d_{t}^{8}$ & & & & & & & & $\begin{array}{c}0.07 * * * \\
(0.02)\end{array}$ & $\begin{array}{c}0.04^{* * *} \\
(0.01)\end{array}$ & $\begin{array}{l}0.02^{*} \\
(0.01)\end{array}$ & $\begin{array}{c}0.04 * * \\
(0.02)\end{array}$ & $\begin{array}{c}0.03^{* * * *} \\
(0.01)\end{array}$ & $\begin{array}{c}0.01 \\
(0.01)\end{array}$ & $\begin{array}{c}0.00 \\
(0.001)\end{array}$ \\
\hline Constant & & & & & & & $\begin{array}{c}-0.02 * * * \\
(0.01)\end{array}$ & & & & & & & $\begin{array}{r}-0.01^{* *} \\
(0.01)\end{array}$ \\
\hline \multicolumn{15}{|l|}{ Fixed effects } \\
\hline Austria & $-0.63^{*}$ & $-0.69 *$ & -0.55 & -0.51 & -0.43 & -0.40 & & -0.45 & -0.58 & -0.45 & -0.42 & -0.35 & -0.37 & \\
\hline Belgium & -0.21 & -0.05 & -0.060 & -0.090 & -0.100 & -0.100 & & -0.17 & -0.02 & -0.02 & -0.06 & -0.06 & -0.08 & \\
\hline Germany & $-0.24 * * *$ & $-0.19^{* * *}$ & $-0.25 * *$ & -0.02 & -0.04 & -0.02 & & 0.047 & -0.01 & -0.08 & $0.12 * *$ & $0.07 *$ & 0.02 & \\
\hline Greece & $-2.24 * *$ & $-2.13 * * *$ & $-1.57 * *$ & $-1.18^{* *}$ & -0.76 & -0.49 & & $-1.79 * *$ & $-1.85^{* *}$ & $-1.3^{* *}$ & -0.94 & -0.56 & -0.42 & \\
\hline Denmark & -0.25 & -0.21 & -0.24 & -0.17 & -0.21 & -0.15 & & $-0.51 * *$ & $-0.37 *$ & $-0.4 * *$ & -0.28 & $-0.29 *$ & -0.17 & \\
\hline Spain & $-0.38^{* * *}$ & $-0.43 * * *$ & $-0.34 * * *$ & $-0.22 * * *$ & $-0.14 * * *$ & $-0.12 * *$ & & $-0.32^{* * *}$ & $-0.40^{* * *}$ & $-0.29 * * *$ & $-0.18^{* * *}$ & $-0.08^{* * *}$ & $-0.1 * * *$ & \\
\hline Finland & $0.28^{* *}$ & $0.32^{* * *}$ & 0.17 & 0.11 & 0.05 & 0.02 & & -0.12 & 0.08 & -0.03 & -0.05 & -0.04 & -0.02 & \\
\hline France & $-0.13^{*}$ & $-0.11^{* *}$ & $-0.14^{*}$ & -0.07 & -0.06 & -0.04 & & $0.19^{* *}$ & $0.10^{*}$ & 0.07 & 0.09 & 0.06 & 0.00 & \\
\hline Ireland & 0.10 & 0.12 & 0.170 & 0.130 & $0.12 *$ & $0.1^{*}$ & & -0.08 & -0.002 & 0.06 & 0.040 & 0.06 & 0.080 & \\
\hline Italy & $-0.66^{* * *}$ & $-0.51^{* * * *}$ & $-0.35^{* * *}$ & $-0.24 * *$ & $-0.19^{* *}$ & $-0.14^{*}$ & & -0.36 & $-0.31 *$ & -0.16 & -0.09 & -0.06 & -0.09 & \\
\hline Luxembourg & $0.81^{* * *}$ & 0.00 & -0.010 & -0.080 & -0.050 & -0.090 & & $0.55^{* *}$ & -0.19 & -0.20 & -0.230 & $-0.16^{*}$ & -0.13 & \\
\hline Netherlands & -0.04 & -0.09 & $-0.1^{*}$ & -0.01 & 0.02 & -0.02 & & 0.03 & -0.05 & -0.05 & 0.03 & 0.05 & 0.00 & \\
\hline Portugal & $-0.81^{* * *}$ & $-0.53^{* * *}$ & $-0.5^{* * *}$ & $-0.23^{*}$ & $-0.23^{* *}$ & $-0.15^{* *}$ & & -0.44 & $-0.29 *$ & $-0.28^{*}$ & -0.04 & -0.09 & $-0.101^{*}$ & \\
\hline Sweden & $-0.61^{*}$ & $-0.66^{*}$ & -0.41 & -0.48 & 0.14 & 0.12 & & $-0.92 * *$ & $-0.91 * *$ & -0.52 & $-0.56^{*}$ & 0.11 & 0.11 & \\
\hline United Kingdom & $-0.25^{* * *}$ & $-0.24 * * *$ & $-0.18^{* * *}$ & $-0.13 * * *$ & $-0.09 * *$ & $-0.05^{*}$ & & -0.17 & $-0.20^{* *}$ & $-0.12 * *$ & -0.08 & -0.03 & -0.03 & \\
\hline $\begin{array}{l}\text { Redundant fixed effects } \\
\text { test (p-val) }\end{array}$ & 0.00 & 0.00 & 0.00 & 0.01 & 0.03 & 0.07 & 0.17 & 0.00 & 0.00 & 0.01 & 0.00 & 0.01 & 0.07 & 0.13 \\
\hline $\mathbf{R}^{2}$ & 0.36 & 0.42 & 0.34 & 0.22 & 0.17 & 0.16 & 0.00 & 0.35 & 0.38 & 0.25 & 0.27 & 0.23 & 0.16 & 0.00 \\
\hline $\begin{array}{l}\mathrm{H}_{0}: \boldsymbol{\alpha}_{\mathrm{i}}=\mathbf{0}, \boldsymbol{\beta}_{\mathrm{i}}=\mathbf{0} \\
(\mathrm{p} \text {-value) }\end{array}$ & 0.00 & 0.00 & 0.00 & 0.00 & 0.00 & 0.00 & 0.03 & 0.00 & 0.00 & 0.00 & 0.00 & 0.00 & 0.00 & 0.03 \\
\hline $\mathrm{N}^{\circ}$ of observations & 119 & 119 & 133 & 133 & 148 & 148 & 164 & 119 & 119 & 133 & 133 & 148 & 148 & 164 \\
\hline \multicolumn{15}{|l|}{ Memorandum item: } \\
\hline $\begin{array}{l}\text { Constant estimated in } \\
\text { model without fixed-effects }\end{array}$ & $\begin{array}{c}-0.35^{* * * *} \\
(0.04)\end{array}$ & $\begin{array}{c}-0.36^{* * *} \\
(0.02)\end{array}$ & $\begin{array}{c}-0.29 * * * \\
(0.02)\end{array}$ & $\begin{array}{c}-0.21^{* * *} \\
(0.02)\end{array}$ & $\begin{array}{l}-0.13^{* * *} \\
(0.02)\end{array}$ & $\begin{array}{c}-0.1^{* * *} \\
(0.01)\end{array}$ & & $\begin{array}{c}-0.3 * * * \\
(0.06)\end{array}$ & $\begin{array}{c}-0.33^{* * * *} \\
(0.03)\end{array}$ & $\begin{array}{c}-0.25 * * * \\
(0.03)\end{array}$ & $\begin{array}{c}-0.18^{* * * *} \\
(0.02)\end{array}$ & $\begin{array}{c}-0.09 * * * \\
(0.02)\end{array}$ & $\begin{array}{c}-0.09^{* * *} \\
(0.01)\end{array}$ & \\
\hline
\end{tabular}

Notes: Standard errors in parentheses. The symbols * $* *$ and $* * *$ denote significance at the $10 \%, 5 \%$ and $1 \%$ significance levels, respectively. The Wald coefficient test follows a $\chi^{2}$ with degrees of freedom equal to the number of restrictions. The estimated coefficients correspond to the fixed-effects specification provided that these effects are jointly significant. Otherwise, the no-fixed effects specification is shown. When the model was estimated with fixed effects we tested the joint significance of $\alpha_{i}$ and $\beta_{i}$, where $\alpha_{i}$ was the weighted average of the different 15 fixed effects. Thus, the model can be re-written such that the different fixed effects are expressed as deviations from a "common" constant. 
Table 5: Additional rationality tests. Estimation of equation (5): $r_{t}^{8, v}=\alpha+\beta d_{t}^{v}+\gamma E_{H}$ [ $\left.\mathrm{g}_{\mathrm{H}}{ }^{v}\right]+\delta \mathrm{E}_{\mathrm{H}}\left[\right.$ ELECTIONS $\left._{\mathrm{H}}{ }^{v}\right]+\varepsilon_{\mathrm{t}}^{v}$

\begin{tabular}{|c|c|c|c|c|c|c|c|}
\hline & $v=1$ & $v=2$ & $v=3$ & $v=4$ & $v=5$ & $v=6$ & $v=7$ \\
\hline$d_{t}^{v}$ & $\begin{array}{c}-0.06^{* * *} \\
(0.02)\end{array}$ & $\begin{array}{c}-0.03 * * * \\
(0.01)\end{array}$ & $\begin{array}{c}-0.04^{* *} \\
(0.02)\end{array}$ & $\begin{array}{l}-0.02 \\
(0.02)\end{array}$ & $\begin{array}{l}-0.01 \\
(0.01)\end{array}$ & $\begin{array}{c}0.001 \\
(0.007)\end{array}$ & $\begin{array}{l}-0.002 \\
(0.001)\end{array}$ \\
\hline $\mathbf{E}_{\mathbf{H}}\left[\mathbf{g}_{\mathrm{H}}{ }^{\mathrm{v}}\right]$ & $\begin{array}{c}0.07 * * * \\
(0.03)\end{array}$ & $\begin{array}{l}0.03 * * \\
(0.01)\end{array}$ & $\begin{array}{l}-0.01 \\
(0.02)\end{array}$ & $\begin{array}{l}-0.03 \\
(0.02)\end{array}$ & $\begin{array}{l}-0.01 \\
(0.01)\end{array}$ & $\begin{array}{l}0.002 \\
(0.01)\end{array}$ & $\begin{array}{l}-0.001 \\
(0.002)\end{array}$ \\
\hline $\mathbf{E}_{\mathrm{H}}\left[\operatorname{ELECTIONS}_{\mathrm{H}}{ }^{\mathrm{v}}\right]$ & $\begin{array}{c}-0.17^{* *} \\
(0.07)\end{array}$ & $\begin{array}{l}-0.11^{* *} \\
(0.05)\end{array}$ & $\begin{array}{l}-0.11 * \\
(0.06)\end{array}$ & $\begin{array}{l}-0.08 \\
(0.05)\end{array}$ & $\begin{array}{l}0.001 \\
(0.05)\end{array}$ & $\begin{array}{c}0.02 \\
(0.036)\end{array}$ & $\begin{array}{c}0.01 \\
(0.016)\end{array}$ \\
\hline Constant & & & & & & $\begin{array}{c}-0.05^{* *} \\
(0.02)\end{array}$ & $\begin{array}{c}-0.02^{* *} \\
(0.01)\end{array}$ \\
\hline \multicolumn{8}{|l|}{ Fixed effects } \\
\hline Austria & $-0.75^{* *}$ & $-0.71^{*}$ & -0.5 & -0.43 & -0.4 & & \\
\hline Belgium & -0.33 & -0.08 & -0.02 & -0.02 & -0.07 & & \\
\hline Germany & $-0.32 * * *$ & $-0.2 * * *$ & $-0.18^{*}$ & 0.048 & 0.00 & & \\
\hline Greece & $-2.48 * * *$ & $-2.2 * * *$ & $-1.49 * *$ & $-1.05^{*}$ & -0.70 & & \\
\hline Denmark & -0.33 & -0.23 & -0.21 & -0.1 & -0.19 & & \\
\hline Spain & $-0.55 * * *$ & $-0.49 * * *$ & $-0.29 * * *$ & -0.12 & $-0.09^{*}$ & & \\
\hline Finland & 0.12 & $0.27 * * *$ & 0.19 & 0.19 & 0.09 & & \\
\hline France & $-0.29 * * *$ & $-0.15^{* * *}$ & -0.08 & 0.01 & -0.02 & & \\
\hline Ireland & -0.27 & -0.03 & 0.21 & $0.28^{*}$ & $0.18^{*}$ & & \\
\hline Italy & $-0.76^{* * *}$ & $-0.52 * * *$ & $-0.29 * *$ & -0.18 & $-0.16^{*}$ & & \\
\hline Luxembourg & $0.6^{* *}$ & -0.09 & 0.02 & 0.03 & -0.01 & & \\
\hline Netherlands & -0.17 & -0.12 & -0.05 & 0.054 & 0.05 & & \\
\hline Portugal & $-0.9^{* * *}$ & $-0.53 * * *$ & $-0.43 * * *$ & -0.15 & $-0.2 * *$ & & \\
\hline Sweden & $-0.74 *$ & $-0.71 *$ & -0.32 & -0.33 & 0.16 & & \\
\hline United Kingdom & $-0.4 * * *$ & $-0.28 * * *$ & $-0.13 * * *$ & -0.04 & -0.05 & & \\
\hline $\begin{array}{l}\text { Redundant fixed effects } \\
\text { test (p-value) }\end{array}$ & 0.00 & 0.00 & 0.00 & 0.01 & 0.06 & 0.11 & 0.13 \\
\hline $\mathbf{R}^{2}$ & 0.41 & 0.43 & 0.33 & 0.23 & 0.16 & 0.00 & 0.01 \\
\hline $\begin{array}{l}\mathrm{H}_{0}: \alpha_{1}=0, \beta_{1}=0, \gamma=0, \delta=0 \\
\text { (p-value) }\end{array}$ & 0.00 & 0.00 & 0.00 & 0.00 & 0.00 & 0.00 & 0.00 \\
\hline$N^{0}$ of pool observations & 119 & 119 & 134 & 134 & 149 & 149 & 164 \\
\hline \multicolumn{8}{|l|}{ Memorandum items: } \\
\hline $\begin{array}{l}\text { Constant estimated in } \\
\text { model without fixed-effects }\end{array}$ & $\begin{array}{c}-0.51 * * * \\
(0.08)\end{array}$ & $\begin{array}{c}-0.41 * * * \\
(0.04)\end{array}$ & $\begin{array}{c}-0.24 * * * \\
(0.04)\end{array}$ & $\begin{array}{c}-0.12^{* *} \\
(0.06)\end{array}$ & $\begin{array}{c}-0.09 * * \\
(0.04)\end{array}$ & & \\
\hline
\end{tabular}

Notes: Standard errors in parentheses. The symbols *,** and *** denote significance at the $10 \%, 5 \%$ and $1 \%$ significance levels, respectively. The Wald coefficient test follows a $\chi^{2}$ with degrees of freedom equal to the number of restrictions. The estimated coefficients correspond to the fixed-effects specification provided that these effects are jointly significant. Otherwise, the no-fixed effects specification is shown. 
Table 6: The role of elections: a zoom. Estimation of (5), for $v=1$, using different definitions of the variable "elections".

\begin{tabular}{lccccc}
\hline $\mathbf{d}_{\mathbf{t}}{ }^{1}$ & $-0.06^{* * *}$ & $-0.06^{* * *}$ & $-0.07^{* * *}$ & $-0.05^{* *}$ & $-0.05^{* *}$ \\
& $(0.02)$ & $(0.02)$ & $(0.02)$ & $(0.02)$ & $(0.02)$ \\
$\mathbf{E}_{\mathbf{H}}\left[\mathbf{g}_{\mathbf{H}}{ }^{1}\right]$ & $0.07^{* * *}$ & $0.09^{* * *}$ & $0.09^{* * *}$ & $0.08^{* *}$ & $0.07 * *$ \\
& $(0.03)$ & $(0.03)$ & $(0.03)$ & $(0.03)$ & $(0.03)$ \\
$\mathbf{E}_{\mathbf{H}}\left[\right.$ ELECTIONS $\left._{\mathbf{H}}{ }^{1}\right]$ & $-0.17^{* *}$ & & & & -0.05 \\
& $(0.07)$ & & & & $(0.07)$ \\
Post-electoral year & & $0.07^{*}$ & & & 0.03 \\
& & $(0.04)$ & & & $(0.04)$
\end{tabular}

\section{Electoral year}

$-0.01$

(0.04)

\section{Pre-electoral year}

\section{Fixed effects}

\begin{tabular}{|c|c|c|c|c|c|}
\hline Austria & $-0.75 * *$ & $-0.86^{* *}$ & $-0.84 * *$ & $-0.73 * *$ & $-0.73^{* *}$ \\
\hline Belgium & -0.33 & -0.43 & -0.41 & -0.33 & -0.32 \\
\hline Germany & $-0.32 * * *$ & $-0.42 * * *$ & $-0.41 * * *$ & $-0.32 * * *$ & $-0.31 * * *$ \\
\hline Greece & $-2.48 * * *$ & $-2.6 * * *$ & $-2.6 * * *$ & $-2.47 * * *$ & $-2.45^{* * *}$ \\
\hline Denmark & -0.33 & -0.42 & -0.39 & -0.36 & -0.35 \\
\hline Spain & $-0.55 * * *$ & $-0.66 * * *$ & $-0.64 * * *$ & $-0.55 * * *$ & $-0.54 * * *$ \\
\hline Finland & 0.12 & 0.01 & 0.05 & 0.09 & 0.09 \\
\hline France & $-0.29 * * *$ & $-0.38 * * *$ & $-0.37 * * *$ & $-0.28 * *$ & $-0.27 * * *$ \\
\hline Ireland & -0.27 & -0.40 & -0.38 & -0.30 & -0.28 \\
\hline Italy & $-0.76 * * *$ & $-0.84 * * *$ & $-0.84 * * *$ & $-0.75 * * *$ & $-0.74 * * *$ \\
\hline Luxembourg & $0.6^{* *}$ & $0.48 *$ & $0.51^{*}$ & $0.58^{*}$ & $0.59 * *$ \\
\hline Netherlands & -0.17 & -0.26 & -0.24 & -0.14 & -0.14 \\
\hline Portugal & $-0.9 * * *$ & $-1.02 * * *$ & $-1.01 * * *$ & $-0.89 * * *$ & $-0.88^{* * *}$ \\
\hline Sweden & $-0.74 *$ & $-0.84 * *$ & $-0.81 * *$ & $-0.76 * *$ & $-0.76^{* *}$ \\
\hline United Kingdom & $-0.4 * * *$ & $-0.5 * * *$ & $-0.48 * * *$ & $-0.4 * * *$ & $-0.39 * * *$ \\
\hline \multicolumn{6}{|l|}{ edundant fixed effects } \\
\hline st (p-value) & 0.00 & 0.00 & 0.00 & 0.00 & 0.00 \\
\hline & 0.41 & 0.40 & 0.40 & 0.41 & 0.42 \\
\hline $\begin{array}{l}0: \alpha_{1}=0, \beta_{1}=0, \gamma=0, \delta=0 \\
\text {-value) }\end{array}$ & 0.00 & 0.00 & 0.00 & 0.00 & 0.00 \\
\hline of pool observations & 119 & 119 & 119 & 119 & 119 \\
\hline \multicolumn{6}{|l|}{ emorandum items: } \\
\hline $\begin{array}{l}\text { Constant estimated in } \\
\text { model without fixed-effects }\end{array}$ & $\begin{array}{c}-0.51 * * * \\
(0.08)\end{array}$ & $\begin{array}{c}-0.61 * * * \\
(0.09)\end{array}$ & $\begin{array}{c}-0.59 * * * \\
(0.11)\end{array}$ & $\begin{array}{c}-0.51 * * * \\
(0.1)\end{array}$ & $\begin{array}{c}-0.5^{* * *} \\
(0.09)\end{array}$ \\
\hline
\end{tabular}

Notes: Standard errors in parentheses. The symbols *,** and *** denote significance at the $10 \%, 5 \%$ and $1 \%$ significance levels, respectively. The Wald coefficient test follows a $\chi^{2}$ with degrees of freedom equal to the number of restrictions. The estimated coefficients correspond to the fixed-effects specification provided that these effects are significant. Otherwise, the no-fixed effects specification is shown. 
Table 7: The role of the fiscal rules index. Estimation of (5), for $v=1$, using different definitions of the variable "elections".

\begin{tabular}{|c|c|c|c|c|c|}
\hline Constant & $\begin{array}{c}-0.53 * * * \\
(0.09)\end{array}$ & $\begin{array}{c}-0.55 * * * \\
(0.09)\end{array}$ & $\begin{array}{c}-0.55^{* * * *} \\
(0.09)\end{array}$ & $\begin{array}{c}-0.49 * * * \\
(0.08)\end{array}$ & $\begin{array}{c}-0.47 * * * \\
(0.07)\end{array}$ \\
\hline$d_{t}{ }^{1}$ & $\begin{array}{l}-0.03 * \\
(0.02)\end{array}$ & $\begin{array}{l}-0.03 \\
(0.02)\end{array}$ & $\begin{array}{l}-0.03 * \\
(0.02)\end{array}$ & $\begin{array}{l}-0.03 * \\
(0.02)\end{array}$ & $\begin{array}{l}-0.03^{*} \\
(0.02)\end{array}$ \\
\hline $\mathbf{E}_{\mathbf{H}}\left[\mathbf{g}_{\mathbf{H}}{ }^{1}\right]$ & $\begin{array}{c}0.09 * * * \\
(0.03)\end{array}$ & $\begin{array}{c}0.09 * * * \\
(0.03)\end{array}$ & $\begin{array}{c}0.089 * * * \\
(0.03)\end{array}$ & $\begin{array}{c}0.08^{* * * *} \\
(0.03)\end{array}$ & $\begin{array}{c}0.08^{* * * *} \\
(0.03)\end{array}$ \\
\hline $\mathbf{E}_{\mathrm{H}}\left[\operatorname{ELECTIONS}_{\mathrm{H}}{ }^{1}\right]$ & $\begin{array}{l}-0.07 \\
(0.13)\end{array}$ & & & & $\begin{array}{l}-0.04 \\
(0.13)\end{array}$ \\
\hline Post-electoral year & & $\begin{array}{c}0.02 \\
(0.09)\end{array}$ & & & $\begin{array}{l}-0.03 \\
(0.1)\end{array}$ \\
\hline Electoral year & & & $\begin{array}{c}0.04 \\
(0.07)\end{array}$ & & \\
\hline Pre-electoral year & & & & $\begin{array}{l}-0.13^{*} \\
(0.07)\end{array}$ & $\begin{array}{c}-0.128^{* *} \\
(0.06)\end{array}$ \\
\hline FRI $_{t}$ & $\begin{array}{l}0.16^{* *} \\
(0.06)\end{array}$ & $\begin{array}{l}0.16^{* *} \\
(0.06)\end{array}$ & $\begin{array}{l}0.16^{* *} \\
(0.06)\end{array}$ & $\begin{array}{c}0.16^{* * *} \\
(0.06)\end{array}$ & $\begin{array}{l}0.16^{* *} \\
(0.06)\end{array}$ \\
\hline $\begin{array}{l}\mathrm{H}_{0}: \alpha_{1}=0, \beta_{1}=0 \\
\text { (p-value) }\end{array}$ & 0.00 & 0.00 & $\mathbf{0 . 0 0}$ & 0.00 & 0.00 \\
\hline $\begin{array}{l}\mathbf{H}_{0}: \boldsymbol{\alpha}_{1}=\mathbf{0}, \boldsymbol{\beta}_{1}=0, \gamma=0, \delta=0 \\
\text { (p-value) }\end{array}$ & 0.00 & 0.00 & 0.00 & 0.00 & 0.00 \\
\hline $\mathrm{N}^{0}$ of pool obse rvations & 119 & 119 & 119 & 119 & 119 \\
\hline
\end{tabular}


Table 8: The role of Eurostat's methodological decisions. Estimation of (5), adding dummy variables on Eurostat decisions.

\begin{tabular}{|c|c|c|c|c|c|c|c|}
\hline & $v=1$ & $v=2$ & $\mathbf{v}=\mathbf{3}$ & $v=4$ & $v=5$ & $v=6$ & $v=7$ \\
\hline Eurostat decisions at $v=2$ & $-1.1 * * *$ & & & & & & \\
\hline Eurostat decisions at $v=3$ & -0.03 & 0.02 & & & & & \\
\hline Eurostat decisions at $v=4$ & -0.37 & -0.46 & -0.54 & & & & \\
\hline Eurostat decisions at $v=5$ & $-0.45^{* *}$ & -0.15 & -0.08 & $-0.11 * * *$ & & & \\
\hline Eurostat decisions at $v=6$ & $-1.1 * * *$ & $-0.48 * * *$ & $-0.5^{* * *}$ & $-0.45^{* * *}$ & $-0.39 * * *$ & & \\
\hline Eurostat decisions at $v=7$ & -0.27 & -0.29 & $-0.75^{*}$ & $-0.8^{*}$ & $-0.18^{* *}$ & $-0.18^{* * *}$ & \\
\hline Eurostat decisions at $v=8$ & $-1.18 * * *$ & $-1.04 * * *$ & $-1.18 * * *$ & $-0.72 * * *$ & $-0.65 * * *$ & $-0.43 * * *$ & $-0.44 * * *$ \\
\hline Constant & & & $\begin{array}{c}-0.12^{* * *} \\
(0.04)\end{array}$ & $\begin{array}{c}0.04 \\
(0.04)\end{array}$ & $\begin{array}{l}-0.03 \\
(0.05)\end{array}$ & $\begin{array}{l}-0.05 * \\
(0.03)\end{array}$ & $\begin{array}{l}-0.01 * \\
(0.01)\end{array}$ \\
\hline \multicolumn{8}{|l|}{ Fixed effects } \\
\hline Austria & $-0.52 * * *$ & $-0.5 * *$ & & & & & \\
\hline Belgium & 0.050 & 0.100 & & & & & \\
\hline Germany & $-0.35^{* * *}$ & $-0.2 * *$ & & & & & \\
\hline Greece & -0.93 & $-1.45^{* *}$ & & & & & \\
\hline Denmark & -0.18 & -0.2 & & & & & \\
\hline Spain & -0.26 & -0.26 & & & & & \\
\hline Finland & 0.17 & $0.25^{* * *}$ & & & & & \\
\hline France & -0.23 & -0.11 & & & & & \\
\hline Ireland & -0.160 & -0.050 & & & & & \\
\hline Italy & -0.35 & -0.33 & & & & & \\
\hline Luxembourg & 0.540 & -0.110 & & & & & \\
\hline Netherlands & -0.19 & -0.13 & & & & & \\
\hline Portugal & $-0.47^{* *}$ & $-0.28 * * *$ & & & & & \\
\hline Sweden & -0.67 & -0.62 & & & & & \\
\hline United Kingdom & $-0.43 * * *$ & $-0.29 * * *$ & & & & & \\
\hline $\begin{array}{l}\text { Redundant fixed effects } \\
\text { test (p-value) }\end{array}$ & 0.01 & 0.00 & 0.26 & 0.17 & 0.20 & 0.21 & 0.05 \\
\hline $\mathbf{R}^{2}$ & 0.60 & 0.52 & 0.39 & 0.31 & 0.20 & 0.17 & 0.32 \\
\hline $\mathrm{N}^{\mathrm{o}}$ of pool observations & 119 & 119 & 134 & 134 & 149 & 149 & 164 \\
\hline \multicolumn{8}{|l|}{ Memorandum items: } \\
\hline $\begin{array}{l}\text { Constant estimated in } \\
\text { model without fixed-effects }\end{array}$ & $\begin{array}{l}-0.27^{*} \\
(0.15)\end{array}$ & $\begin{array}{c}-0.28 * * * \\
(0.07)\end{array}$ & & & & & \\
\hline
\end{tabular}

Notes: Standard errors in parentheses. The symbols *,** and *** denote significance at the $10 \%, 5 \%$ and $1 \%$ significance levels, respectively. The Wald coefficient test follows a $\chi^{2}$ with degrees of freedom equal to the number of restrictions. The estimated coefficients correspond to the fixed-effects specification provided that these effects are significant. Otherwise, the no-fixed effects specification is shown. 
Table 9: News-noise and unbiasedness tests by country size.

\begin{tabular}{|c|c|c|c|c|c|c|c|c|}
\hline & \multicolumn{4}{|c|}{ Equation (3): $r_{t}^{8, v}=\alpha_{1}+\beta_{1} d_{t}^{v}+\varepsilon_{t}^{v}$} & \multicolumn{4}{|c|}{ Equation (4): $r_{t}^{8, v}=\alpha_{2}+\beta_{2} d_{t}^{8}+\varepsilon_{t}^{8}$} \\
\hline & \multicolumn{2}{|c|}{ Big countries } & \multicolumn{2}{|c|}{ Small countries } & \multicolumn{2}{|c|}{ Big countries } & \multicolumn{2}{|c|}{ Small countries } \\
\hline & $v=1$ & $v=4$ & $v=1$ & $v=4$ & $v=1$ & $v=4$ & $v=1$ & $v=4$ \\
\hline$d_{t}^{v}$ & $\begin{array}{c}-0.04 * * * \\
(0.01)\end{array}$ & $\begin{array}{c}0.00 \\
(0.02)\end{array}$ & $\begin{array}{l}-0.05 \\
(0.05)\end{array}$ & $\begin{array}{l}-0.01 \\
(0.02)\end{array}$ & & & & \\
\hline$d_{t}^{8}$ & & & & & $\begin{array}{l}-0.01 \\
(0.02)\end{array}$ & $\begin{array}{c}0.01 \\
(0.01)\end{array}$ & $\begin{array}{c}0.16^{* * *} \\
(0.03)\end{array}$ & $\begin{array}{c}0.04^{* * *} \\
(0.01)\end{array}$ \\
\hline Constant & & & & & & & & $\begin{array}{r}-0.08^{* *} \\
(0.04)\end{array}$ \\
\hline \multicolumn{9}{|l|}{ Fixed effects } \\
\hline Austria & & & -0.64 & -0.50 & & & -0.3 & \\
\hline Belgium & & & -0.21 & -0.08 & & & -0.140 & \\
\hline Germany & $-0.22 * * *$ & 0.02 & & & $-0.15^{* *}$ & 0.05 & & \\
\hline Greece & & & $-2.25 * * *$ & $-1.13^{*}$ & & & -1.38 & \\
\hline Denmark & & & -0.23 & -0.20 & & & $-0.69 * * *$ & \\
\hline Spain & $-0.37 * * *$ & $-0.21 * * *$ & & & $-0.37 * * *$ & $-0.2 * * *$ & & \\
\hline Finland & & & $0.3^{*}$ & 0.07 & & & $-0.41^{*}$ & \\
\hline France & $-0.12 *$ & -0.01 & & & -0.03 & 0.02 & & \\
\hline Ireland & & & 0.11 & 0.11 & & & -0.230 & \\
\hline Italy & $-0.64 * * *$ & $-0.19 *$ & & & $-0.58 * *$ & $-0.16^{*}$ & & \\
\hline Luxembourg & & & $0.82 * * *$ & -0.12 & & & 0.340 & \\
\hline Netherlands & & & -0.05 & 0.00 & & & 0.09 & \\
\hline Portugal & & & $-0.83 * * *$ & $-0.19 *$ & & & -0.14 & \\
\hline Sweden & & & $-0.6^{*}$ & -0.44 & & & $-0.98 * * *$ & \\
\hline United Kingdom & $-0.25 * * *$ & $-0.11 * * *$ & & & $-0.23 * * *$ & $-0.1 * *$ & & \\
\hline $\begin{array}{l}\text { Redundant fixed effects } \\
\text { test (p-value) }\end{array}$ & 0.07 & 0.02 & $\mathbf{0 . 0 0}$ & 0.09 & 0.02 & 0.01 & 0.03 & 0.16 \\
\hline $\mathbf{R}^{2}$ & 0.43 & 0.30 & 0.32 & 0.18 & 0.33 & 0.32 & 0.37 & 0.08 \\
\hline $\begin{array}{l}\mathrm{H}_{0}: \alpha_{1}=0, \beta_{1}=0 \\
\text { (p-value) }\end{array}$ & 0.00 & 0.00 & 0.00 & 0.00 & 0.00 & 0.00 & 0.00 & 0.00 \\
\hline $\mathrm{N}^{0}$ of pool observations & 39 & 44 & 80 & 90 & 39 & 44 & 80 & 90 \\
\hline \multicolumn{9}{|l|}{ Memorandum items: } \\
\hline General constant & $\begin{array}{c}-0.33 * * * \\
(0.03) \\
\end{array}$ & $\begin{array}{c}-0.1 * * * \\
(0.04) \\
\end{array}$ & $\begin{array}{c}-0.36 * * * \\
(0.09)\end{array}$ & $\begin{array}{c}-0.25 * * * \\
(0.03) \\
\end{array}$ & $\begin{array}{c}-0.28 * * * \\
(0.04)\end{array}$ & $\begin{array}{c}-0.08^{* *} \\
(0.03)\end{array}$ & $\begin{array}{c}-0.38 * * * \\
(0.1)\end{array}$ & \\
\hline
\end{tabular}

Notes: Standard errors in parentheses. The symbols $*, * *$ and $* * *$ denote significance at the $10 \%, 5 \%$ and $1 \%$ significance levels, respectively. The Wald coefficient test follows a $\chi^{2}$ with degrees of freedom equal to the number of restrictions. The estimated coefficients correspond to the fixed-effects specification provided that these effects are significant. Otherwise, the no-fixed effects specification is shown. 
Table 10: News-noise and unbiasedness tests for EDP versus non-EDP countries.

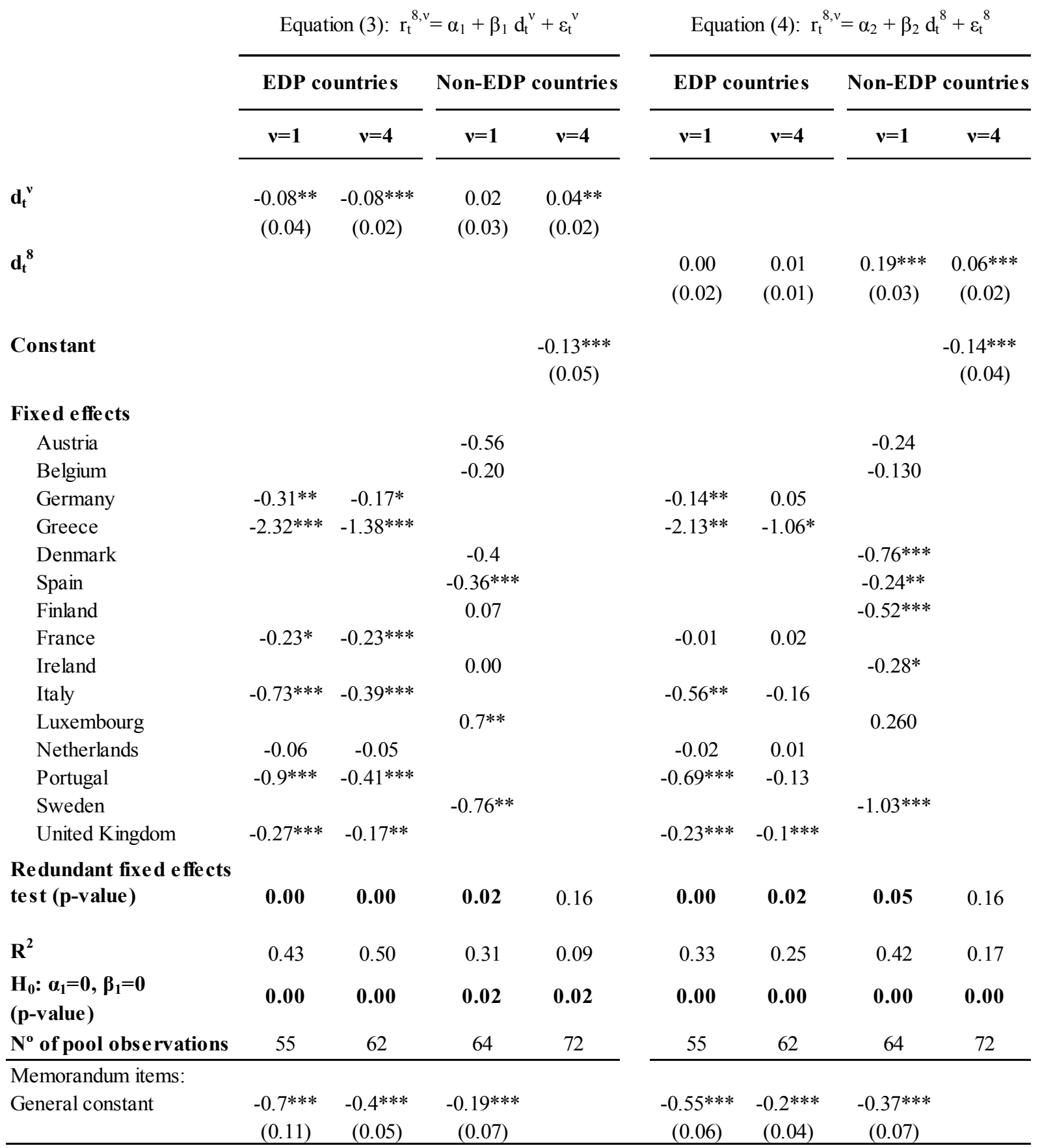

Notes: Standard errors in parentheses. The symbols *, ** and *** denote significance at the $10 \%, 5 \%$ and $1 \%$ significance levels, respectively. The Wald coefficient test follows a $\chi^{2}$ with degrees of freedom equal to the number of restrictions. The estimated coefficients correspond to the fixed-effects specification provided that these effects are significant. Otherwise, the no-fixed effects specification is shown. 
APPENDIX. Table A1: Eurostat decisions leading to revisions.

\begin{tabular}{|c|c|c|c|c|c|c|c|c|c|c|c|c|c|c|c|c|}
\hline \multicolumn{2}{|c|}{ EDP notification } & \multirow[t]{2}{*}{ Austria } & \multirow[t]{2}{*}{ Belgium } & \multirow[t]{2}{*}{ Denmark } & \multirow[t]{2}{*}{ Finland } & \multirow[t]{2}{*}{ France } & \multirow[t]{2}{*}{ Germany } & \multirow[t]{2}{*}{ Greece } & \multirow[t]{2}{*}{ Ireland } & \multirow[t]{2}{*}{ Italy } & \multirow[t]{2}{*}{ Luxembourg } & \multirow[t]{2}{*}{ Netherlands } & \multirow[t]{2}{*}{\begin{tabular}{|l|} 
Portugal \\
\end{tabular}} & \multirow[t]{2}{*}{ Spain } & \multirow[t]{2}{*}{ Sweden } & \multirow[t]{2}{*}{ UK } \\
\hline 1999 & Spring & & & & & & & & & & & & & & & \\
\hline & Autumn & & & & & & & & & & & & & & & \\
\hline \multirow[t]{2}{*}{2000} & Spring & $\begin{array}{c}1996, \\
1997, \\
1998 \\
\end{array}$ & $\begin{array}{c}1996, \\
1997, \\
1998 \\
\end{array}$ & $\begin{array}{l}1996, \\
1997, \\
1998 \\
\end{array}$ & $\begin{array}{l}1996, \\
1997, \\
1998 \\
\end{array}$ & $\begin{array}{c}1996, \\
1997, \\
1998 \\
\end{array}$ & $\begin{array}{l}1996, \\
1997, \\
1998 \\
\end{array}$ & & $\begin{array}{c}1996, \\
1997, \\
1998 \\
\end{array}$ & $\begin{array}{l}1996, \\
1997, \\
1998 \\
\end{array}$ & $\begin{array}{c}1996,1997, \\
1998\end{array}$ & $\begin{array}{c}1996,1997, \\
1998\end{array}$ & $\begin{array}{c}1996, \\
1997, \\
1998\end{array}$ & $\begin{array}{c}1996, \\
1997, \\
1998 \\
\end{array}$ & $\begin{array}{c}1996, \\
1997, \\
1998\end{array}$ & $\begin{array}{l}1996, \\
1997, \\
1998\end{array}$ \\
\hline & Autumn & & & & & & & & & & & & & & & \\
\hline \multirow[t]{2}{*}{2001} & Spring & & & & & & & $\begin{array}{l}1997, \\
1998\end{array}$ & & & & & & & & \\
\hline & Autumn & & & & & & & & & & & & & & & \\
\hline \multirow[t]{2}{*}{2002} & Spring & & & & & & & & & & & & & & & \\
\hline & Autumn & & & & & & & & 2001 & 2001 & & & $\begin{array}{c}1998, \\
1999, \\
2000, \\
2001 \\
\end{array}$ & & & \\
\hline \multirow[t]{2}{*}{2003} & Spring & & & & & $\begin{array}{l}1999, \\
2000, \\
2001, \\
2002\end{array}$ & & & & & & & & & & \\
\hline & Autumn & & & & 2002 & & & & & & & & & & & \\
\hline \multirow[t]{2}{*}{2004} & Spring & & & & & & & & & & & & & & & \\
\hline & Autumn & & & 2003 & & & & $\begin{array}{l}2000, \\
2001, \\
2003\end{array}$ & & & & & & & & \\
\hline \multirow[t]{2}{*}{2005} & Spring & & & & & & & $\begin{array}{l}2002 \\
2003\end{array}$ & & & & & & & & \\
\hline & Autumn & & & & & & & $\begin{array}{l}2001 \\
2002, \\
2003, \\
2004\end{array}$ & & & & & & & & \\
\hline \multirow[t]{2}{*}{2006} & Spring & $\begin{array}{l}2002 \\
2003 \\
2004\end{array}$ & & & & & & & & & & & & & & \\
\hline & Autumn & & 2005 & & & & & $\begin{array}{l}2002 \\
2003 \\
2004 \\
2005\end{array}$ & & & & & & & $\begin{array}{c}2003 \\
2004 \\
2005\end{array}$ & \\
\hline \multirow[t]{2}{*}{2007} & Spring & & & $\begin{array}{l}2003, \\
2004, \\
2005 \\
\end{array}$ & & & & & & & & & & & & \\
\hline & Autumn & 2006 & & & & & & & & & & & & $\begin{array}{l}2003 \\
2004, \\
2005, \\
2006\end{array}$ & 2005 & \\
\hline \multirow[t]{2}{*}{2008} & Spring & 2004 & & & & & & & & 2006 & & & & & & \\
\hline & Autumn & 2004 & $\begin{array}{c}2004 \\
2005 \\
2007\end{array}$ & & & & 2007 & $\begin{array}{r}2006 \\
2007\end{array}$ & & $\begin{array}{l}2004, \\
2005, \\
2006, \\
2007\end{array}$ & & & & & & \\
\hline \multirow[t]{2}{*}{2009} & Spring & & & & & & & & & & & & & & & \\
\hline & Autumn & & & & 2008 & & & 2008 & & & & & & $\begin{array}{r}2007 \\
2008\end{array}$ & & \\
\hline
\end{tabular}


